A-rkivoc

Free to Authors and Readers
A Platinum Open Access Journal for Organic Chemistry
Review

Arkivoc 2021, part i, 471-490

\title{
Recent syntheses of steroidal oxazoles, oxazolines and oxazolidines
}

\author{
Besma Bendif, ${ }^{\mathrm{a}, \mathrm{b}}$ Malika Ibrahim-Ouali, ${ }^{* a}$ and Frédéric Dumur ${ }^{\mathrm{c}}$ \\ ${ }^{a}$ Aix Marseille Univ, CNRS, Centrale Marseille, iSm2, F-13397 Marseille, France \\ ${ }^{b}$ Laboratoire de Chimie Appliquée, Faculté des Sciences, Université du 08 mai 1945 Guelma, Algeria \\ 'Aix Marseille Univ, CNRS, ICR, UMR 72 73, F-13397 Marseille, France \\ Email: malika.ibrahim@univ-amu.fr
}

Received 03-15-2021

Accepted 04-11-2021

Published on line 05-08-2021

\section{Abstract}

It was found that the introduction of heterocycles to steroids often leads in a change of their physiological activity and the appearance of new interesting biological precursors. Recent developments in the syntheses of steroidal oxazoles, oxazolines, and oxazolidines are described herein. The biological activities of those steroidal derivatives for which data are available are given.

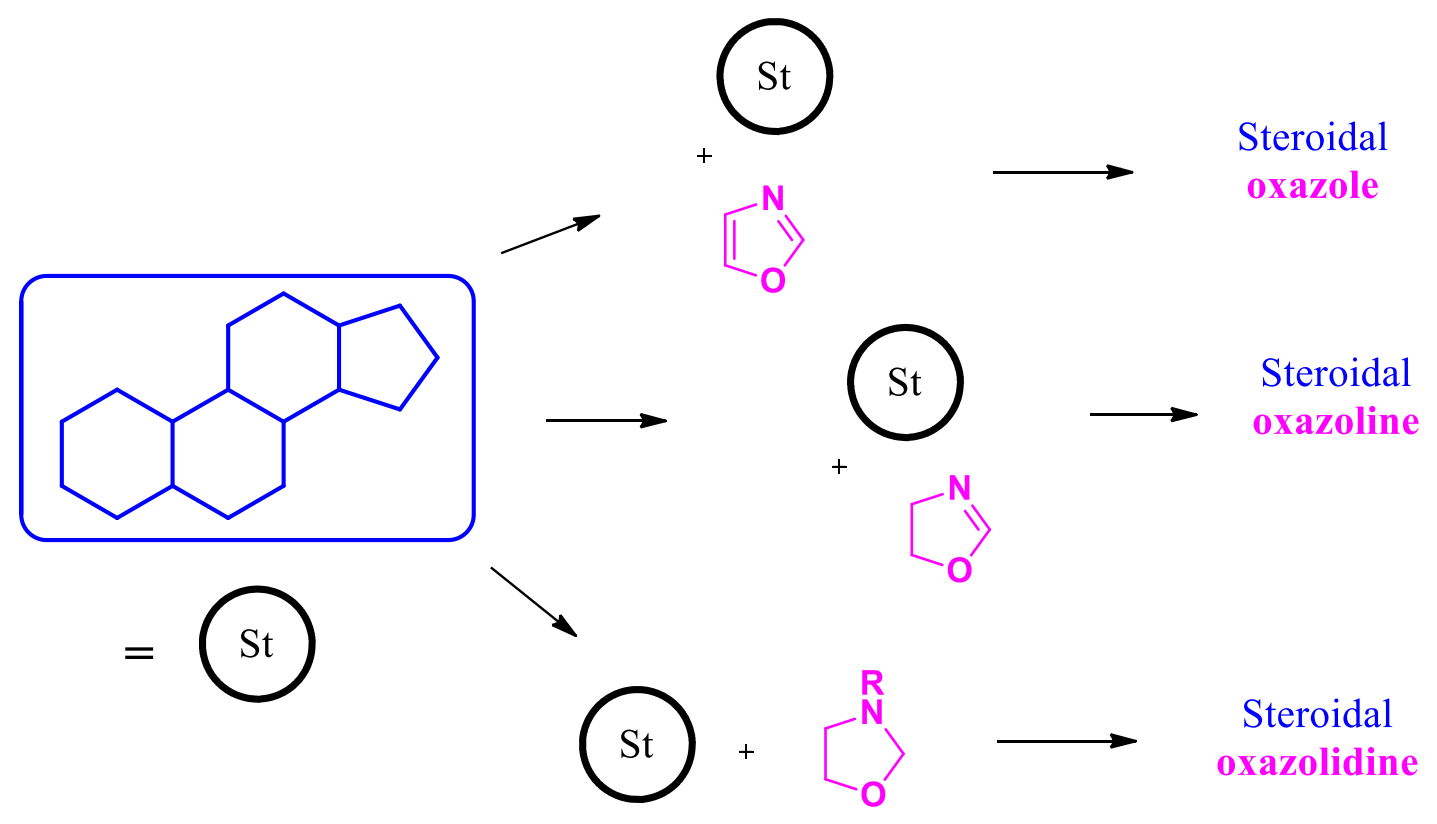

Keywords: Steroids, oxazoles, oxazolines, oxazolidines 


\section{Table of Contents}

1. Introduction

2. Synthesis of Steroidal Oxazoles

3. Synthesis of Steroidal Oxazolines

4. Synthesis of Steroidal Oxazolidines

5. Conclusions

Acknowledgements

References

\section{Introduction}

Steroids constitute an extensive and important class of biologically active polycyclic compounds that are widely used for therapeutic purposes. ${ }^{1-3}$ Even after decades of research, the total synthesis of steroid nuclei by improved strategies continues to receive considerable attention. Numerous methods have been exploited for the total synthesis of steroids which are widely distributed in nature and which possess practical medical importance. Research into steroid total synthesis continues to this day. ${ }^{4,5}$

Heterocycles are widespread in drug molecules because they possess hydrogen bond donors and acceptors in a rigid framework, and they can therefore effectively interact with target enzymes and receptors via hydrogen bond formation. They can enhance binding affinity and improve in vitro potency. Heterocycles can modulate the lipophilicity of the drug molecules or improve the aqueous solubility of the compounds, thus providing desired pharmacokinetic and pharmacodynamic properties. ${ }^{6}$ Heterocyclic compounds are therefore widely applied in pharmaceutical and agrochemical research.

It was found that introducing heterocycles into steroids, ${ }^{7-12}$ by modification of the steroidal side chain or substitution of the steroidal skeleton, can result in a change in its biological activities. ${ }^{13-17}$ Steroids containing heteroatoms have been widely researched and reported. ${ }^{18}$ Literature reports have suggested that such compounds can display distinct cytotoxicity against cancer cell lines. ${ }^{19-22}$

This article provides an overview of the various synthetic strategies which have been employed to synthesize steroidal derivatives containing oxazoles, oxazolines, and oxazolidines along with interesting biological activities, from the years 1996-2021. To the best of our knowledge and much to our surprise, there are no reports on this subject since $1996 .^{23}$

\section{Synthesis of Steroidal Oxazoles}

In 2018, Timofeev et al. ${ }^{24}$ reported the synthesis of benzoxazolyl derivatives 6-9 (Scheme 1) starting from steroid acids $\mathbf{1}, \mathbf{2}, \mathbf{3}, \mathbf{4}$, and $o$-aminophenol. The cyclization step was carried out in the presence of pyridine instead of triethyl amine. Preliminary experiments revealed that cyclization of intermediate amides (shown in brackets) in the presence of strong bases gave target benzoxazoles in low yield, and was accompanied by the formation of a complex mixture of byproducts. If the cyclization step was conducted in the presence of pyridine at $50{ }^{\circ} \mathrm{C}$ during $3 \mathrm{~h}$, the yield of benzoxazoles 6-9 was $>50 \%$, however, in contrast to the synthesis of oxazolines, all these benzoxazoles were obtained as mixtures of two isomers.

Compounds 6-9 in concentrations of $1 \mu \mathrm{M}, 10 \mu \mathrm{M}$, and $30 \mu \mathrm{M}$ did not markedly inhibit CYP17A1 activity. 


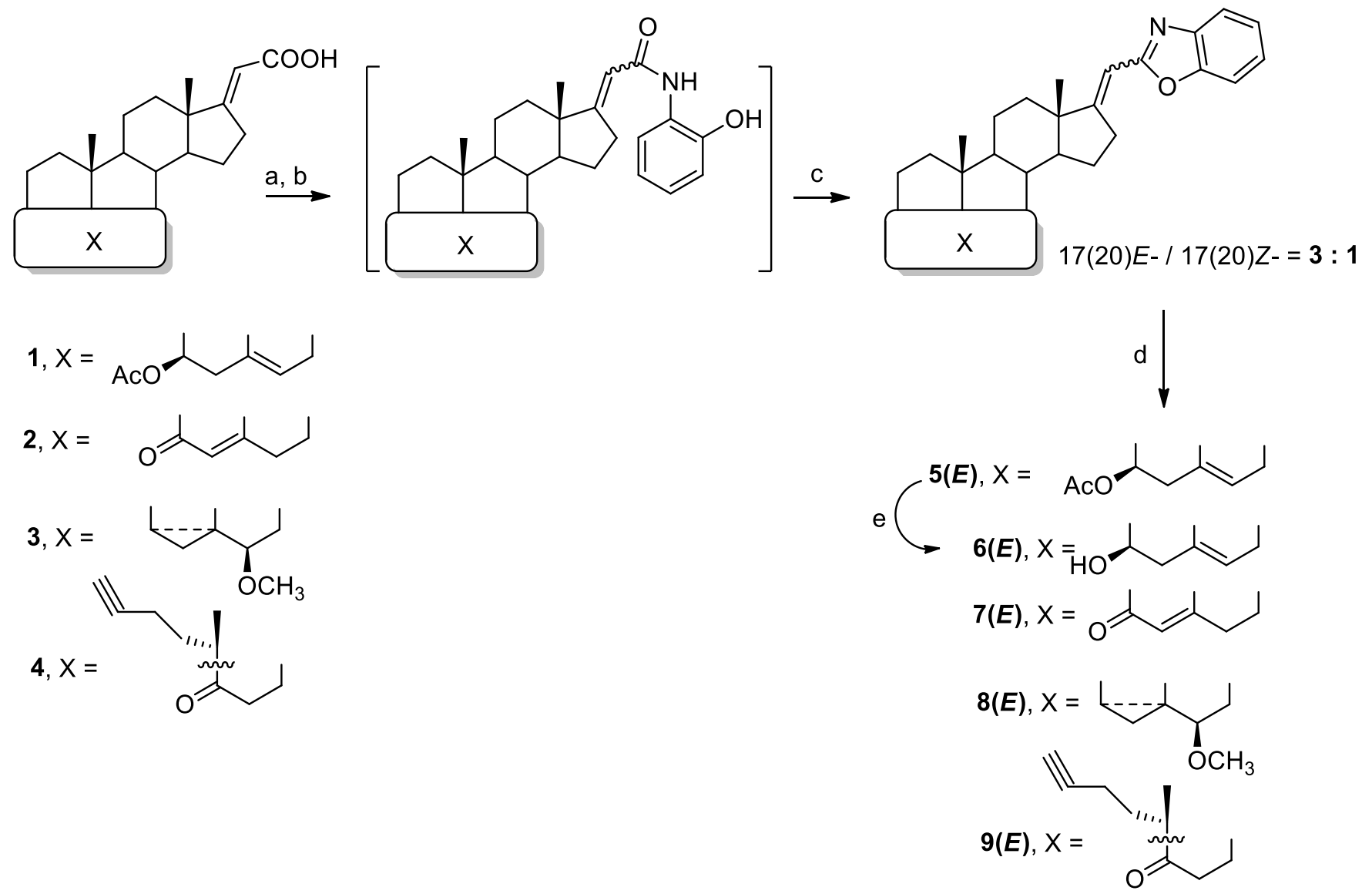

Reagents and conditions: a- $\mathrm{Ph}_{3} \mathrm{P}, \mathrm{CCl}_{4} / \mathrm{CH}_{3} \mathrm{CN}, 2^{\circ} \mathrm{C}, 90$ min; b- o- $\mathrm{NH}_{2}\left(\mathrm{C}_{6} \mathrm{H}_{4}\right) \mathrm{OH}$, pyridine, $2{ }^{\circ} \mathrm{C}$ to $20^{\circ} \mathrm{C}, 30 \mathrm{~min} ; \mathrm{C}-\mathrm{Ph}_{3} \mathrm{P}, \mathrm{CCl}_{4} / \mathrm{CH}_{3} \mathrm{CN}$, pyridine, $50{ }^{\circ} \mathrm{C}, 3 \mathrm{~h}$; d- isolation of $17(20) \mathrm{E}$-isomer; e- $\mathrm{K}_{2} \mathrm{CO}_{3} / \mathrm{CH}_{3} \mathrm{OH}-\mathrm{H}_{2} \mathrm{O}$, reflux, 30 min.

Scheme 1. Synthesis of steroidal oxazole derivatives 5-9.

In 2019 , steroids containing an isoxazole were synthesized by Scherbakov et al. ${ }^{25}$ by a dipolar cycloaddition. The influence of solvents on the result of dipolar cycloaddition and solvolysis of bridged nitrosteroids was evaluated. Cytotoxicity testing of estrone analogs on cancer cells of various origins revealed activity against breast, colorectal, prostate, and lung cancer cells.

The starting nitro adduct 11 was synthesized from estrone 10 by the procedure described by Baranovsky et al. ${ }^{26}$ with some modifications, in particular, in the synthesis of a mixture of $\Delta 14$ - and $\Delta 15$-ketones, DMF was replaced by dimethylacetamide, which much decreased the reaction time and improved the total yield of product (Scheme 2).

Studying the chemical properties of isoxazolyl steroids 12 and 13 they focused on the reductive transformations of their heterocyclic moiety. The presence of the $\Delta 15$ bond in steroids created some difficulties in the selective hydrogenation of this bond. The hydrogenation reaction $\left(\mathrm{Pd} / \mathrm{C}, \mathrm{H} 2 ; \mathrm{Ni} / \mathrm{Ra}, \mathrm{H} 2 ; \mathrm{Pd} / \mathrm{C}, \mathrm{HCO} \mathrm{NH}_{4}\right)$ occurred unselectively: along with the saturation of the double bond, they observed ring-opening and intramolecular Michael cyclization of the ring-opening products to form various C-14-C-15-fused derivatives. Thus, to accomplish the intended purpose, they had to exclude the double bond in steroids $\mathbf{1 2}$ and 13 from conjugation. As known, sodium borohydride can reduce conjugated systems to saturated alcohols. ${ }^{27}$ The same result was obtained in the reduction of steroid 12: the reaction resulted in the preferential formation of a $17 \alpha$ epimer (according to the NMR data, the $17 \alpha / 17 \beta$ ratio was $1.5: 1$ ). Under the reaction conditions, removal of 
the protective group at C3 was also observed. Therefore, the resulting mixture of products was acetylated to obtain triacetates 18 and 19. They could partially separate these products. Isoxazolines $\mathbf{1 4}$ and their 3-hydroxy derivatives 15, unlike isoxazoles, are resistant to Pd-catalyzed hydrogenation, and their reduction afforded steroids 16 and 17, respectively. By repeated chromatography, they could isolate individual isomers of the compound 16.

Treatment of steroid $\mathbf{1 6}$ with $\mathrm{TsOH}$ leads to the elimination of ethanol from the isoxazoline ring to form isoxazoles $\mathbf{2 0}$ and $\mathbf{2 1}$ in a high total yield. To synthesize alcohols they made use of $\Delta 15$-isoxazolines 14, which were reduced with sodium borohydride. Conjugated reduction of $\mathbf{1 4}$ with sodium borohydride, like with steroid 12, resulted in the preferential formation of $17 \alpha$ alcohols (1.5:1) and was accompanied by removal of the protective group at C-3. The mixture of four diastereomers (at C-17 and C-5') was, without separation, acetylated in acidic conditions, where acetylation was accompanied by heteroring aromatization. From the mixture of two epimers of $\mathbf{2 2}$ and $\mathbf{2 3}$, they isolated $17 \alpha$ epimer.

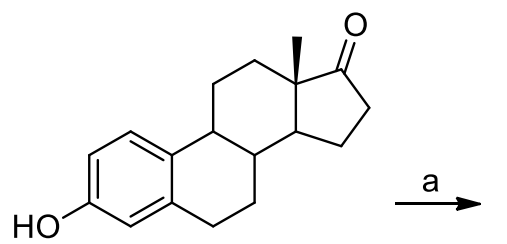

10<smiles>CC(C)C1(O)C=CC2C3CCc4cc(OC(C)(C)C)ccc4C3CCC21C</smiles>

11<smiles>[R6]c1ccc2c(c1)CC[C@@H]1[C@@H]2CC[C@]2(C)C(=O)C=C[C@]12CC1=NO[C@@H](OCC)C1</smiles>

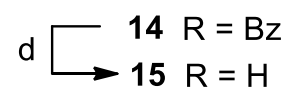<smiles>[R20]c1ccc2c(c1)CC[C@@H]1[C@@H]2CC[C@]2(C)C(=O)CC[C@@]12CC1=NO[C@@H](OCC)C1</smiles>

$16 \mathrm{R}=\mathrm{Bz}$

$17 \mathrm{R}=\mathrm{H}$

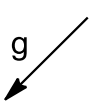

$f$

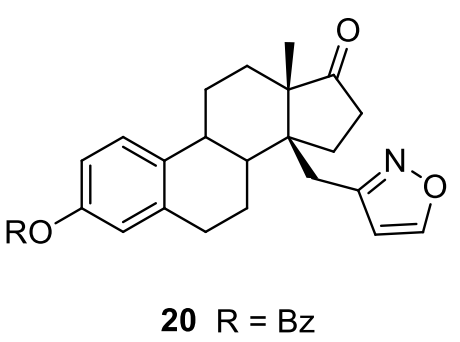

$21 \mathrm{R}=\mathrm{H}$<smiles>CC(=O)Oc1ccc2c(c1)CCC1C2CC[C@]2(C)C(OC(C)=O)CC[C@]12Cc1ccon1</smiles>

22

23

Reagents : a- [28]; b- propargyl acohol, $\mathrm{NaHCO}_{3}$, iPrOH, $\mathrm{H}_{2} \mathrm{O}$, reflux; c- $\mathrm{CH}_{2}=\mathrm{CHOEt}, \mathrm{NaHCO}_{3}$, iPrOH, $\mathrm{H}_{2} \mathrm{O}$, reflux; d- $\mathrm{KOH}, \mathrm{MeOH}, \mathrm{H}_{2} \mathrm{O}$; e- $\mathrm{HCO}_{2} \mathrm{NH}_{4}, \mathrm{Pd} / \mathrm{C}$, EtOH; f- $\mathrm{NaBH}_{4}$, THF, $\mathrm{MeOH}$ then $\mathrm{Ac}_{2} \mathrm{O}, \mathrm{HClO}_{4}, \mathrm{AcOEt} ; \mathrm{g}-\mathrm{TsOH}, \mathrm{MeCN}$.

Scheme 2. Synthesis of steroidal oxazole derivatives 18-23. 
Steroids 13, 15, and 21 were tested for cytostatic activity against a series of human cancer cell lines, specifically, MCF-7, MDA-MB-231, and T-47D breast, HCT 116 colorectal, 22Rv1 prostate, and A549 lung human cancer cell lines. The concentrations of test compounds in the cytostatic activity tests were varied between 6 and $50 \mu \mathrm{M}$. All tested compounds showed a low cytostatic activity at low concentrations (6-25 $\mu \mathrm{M})$. Compound 13 showed the highest activity against MCF-7 hormone-dependent breast cancer cells. Compound 15 inhibited the growth of MDA-MB-231 triple-negative breast cancer cells by $18 \%$, while other steroids were less active. Steroids 13, 15, and 21 showed similar activities against HCT 116 cells ( 25\% growth inhibition). Steroids 13 and $\mathbf{1 5}$ did not show any activity against lung cancer cells, while steroid $\mathbf{2 1}$ inhibited the growth of this cell line. Steroid $\mathbf{2 1}$ was found to be the most active (51\% inhibition of T-47D growth).

In 2019, Figueroa-Valverde et al. ${ }^{29}$ reported a facile synthesis of new steroid-oxazole-1,2'-[1,3] oxazete derivative 27 (Scheme 3). The biological activity exerted by this compound on ischemia/reperfusion injury indicated that compound $\mathbf{2 7}$ exerts a cardioprotective effect by increase the left ventricular pressure via kinase2 inhibition.

The reaction of estradiol $\mathbf{2 4}$ with acetonitrile led to a spiro-steroid ethanimidic acid analog $\mathbf{2 5}$. Then, a nitrospiro-steroid ethanimidic acid $\mathbf{2 6}$ was prepared through a reaction of $\mathbf{2 5}$ with nitric acid. Finally, $\mathbf{2 7}$ was formed via intramolecular displacement of nitro by a hydroxyl group. This reaction involves two reactions mechanism: (a) preparation of an acetamidic acid via reaction of nitrile with the hydroxyl group bound to ring-A; (b) formation of spiro system by the reaction of acetonitrile with the 17-hydroxyl group of steroid derivative.

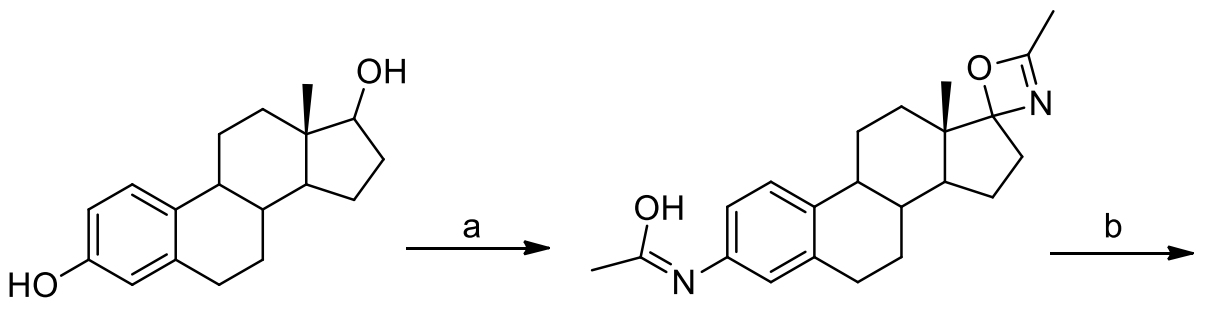

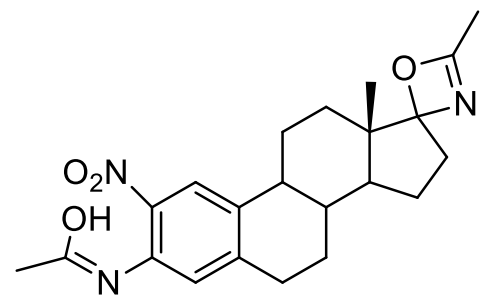

26

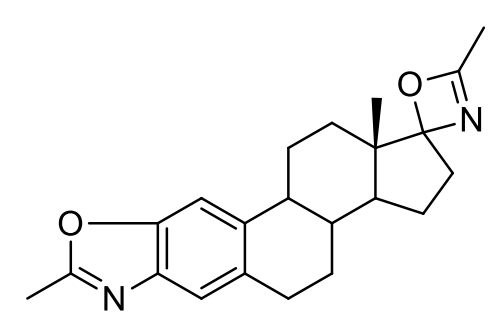

27

Reagents : a- $\mathrm{CH}_{3} \mathrm{CN}$; b- $\mathrm{HNO}_{3}$.

Scheme 3. Synthesis of steroid-oxazole-1,2'-[1,3] oxazete derivative 27.

\section{Synthesis of Steroidal Oxazolines}

In 2014, a series of novel D-ring substituted isoxazoline and oxazoline derivatives of dehydroepiandrosterone and pregnenolone, respectively were synthesized by Banday et al. ${ }^{30}$ and screened for anticancer activity against 
a panel of human prostate cancer cell lines. From the data, it was found that all the compounds are having promising anticancer activity especially against LNCaP and DU-145 cell lines and the compound 33e was found to be the most active in this study.

The starting ketone $\mathbf{2 8}$ upon condensation with ethyl cyanoacetate in boiling toluene, in the presence of ammonium acetate was transformed to Knoevenagel adduct 29 presumably as a mixture of $E$ and $Z$ isomers ( $89 \%$ yield) (Scheme 4). The condensation product was reduced to the saturated alcohol $\mathbf{3 0}$ ( $97 \%$ yield). Hydroxyl group in compound $\mathbf{3 0}$ was then protected as its tetrahydropyranyl (THP) ether and the derivative $\mathbf{3 1}$ was subjected to reduction with an excess of neat di-isobutyl aluminum hydride (DIBAL) for a prolonged period resulting in the formation of two products. The major product was the required one $\mathbf{3 2}$ formed in almost $50 \%$ yield. The intermediate 32 served as an activated olefin having a great potential for the construction of a large number of carbocyclic and heterocyclic analogs across ring $D$ preferably through dipolar cycloadditions. The same was done for the preparation of isoxazoline derivatives $\mathbf{3 3}$ (a-f) by employing the cycloaddition of aromatic nitrile oxides across the olefin 32. Though the cycloaddition could conceptually lead to the formation of two regioisomers, only one regioisomer was isolated.

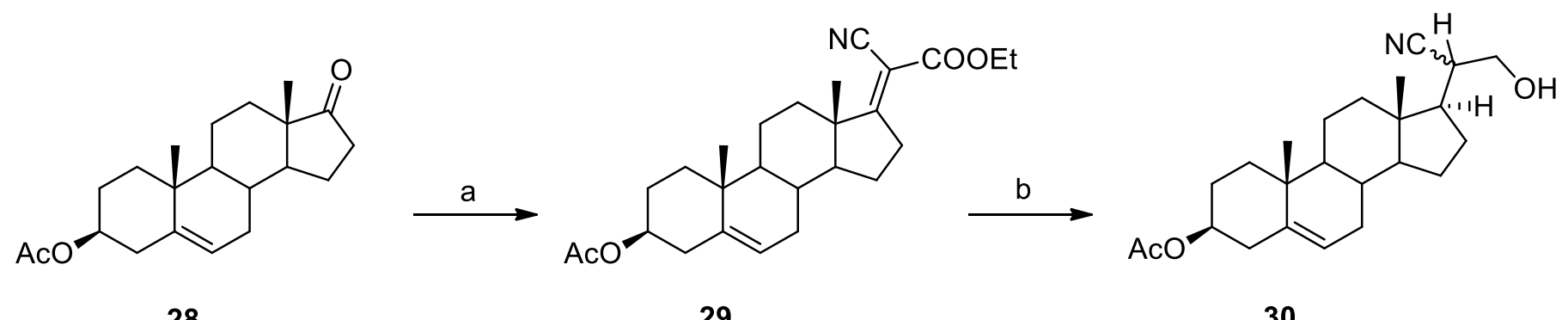

28

29

30

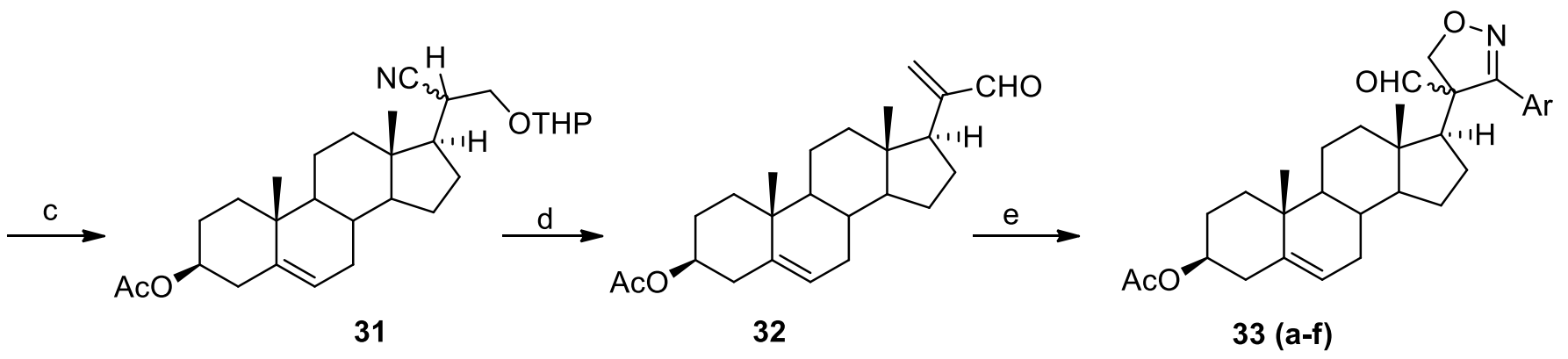

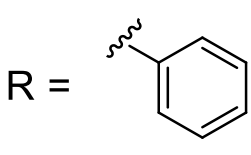

a<smiles>CC(C)(C)c1ccc(Cl)cc1</smiles>

b<smiles>Nc1cccc2cc3ccccc3cc12</smiles>

C<smiles>Cc1ccc(F)cc1</smiles>

d<smiles>COc1ccc(C)cc1</smiles>

e<smiles>Cc1ccccc1[N+](=O)[O-]</smiles>

f

Reagents and conditions: a- $\mathrm{NCCH}_{2} \mathrm{COOEt}, \mathrm{AcOH}, \mathrm{AcNH}_{4} /$ toluene $(90 \%)$; b- $\mathrm{NaBH}_{4} / \mathrm{MeOH}(98 \%)$; c- DHP, p-TSA/DCM (95\%); d- DIBAL neat/toluene/- $78{ }^{\circ} \mathrm{C}$ (50\%); e- Ar-CNO, THF.

Scheme 4. Synthesis of the D-ring dehydroepiandrosterone isoxazolines.

For the synthesis of oxazolines, they followed an efficient strategy earlier described by Wolfing et al. ${ }^{31}$ This strategy involves a one-pot conversion of aldehydes to oxazolines upon reaction with $\alpha, \beta$-azidoalcohols. They 
chose $3 \beta$-acetoxypregn-5-en-20-one 34 as the starting material (Scheme 5). Oxidation with $\mathrm{Pb}(\mathrm{OAc})_{4}$ furnished

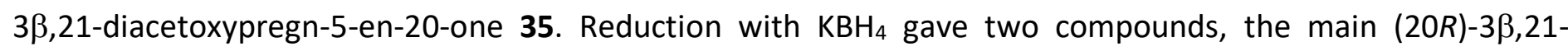
diacetoxypregn-5-en-20-ol, and its 20S-epimer in a very small quantity. The required pure epimer was obtained by flash chromatography. Selective deacetylation on alkaline alumina was carried out by an earlier developed method to obtain the dihydroxy derivative $36 .{ }^{30}$ Chlorination of $\mathbf{3 6}$ in the Appel reaction ${ }^{32}$ produced the (20R)$3 \beta$-acetoxy-21-chloropregn-5-en-20-ol (37). Nucleophilic exchange with $\mathrm{NaN}_{3}$ led to the required (20R)-3 $\beta$ acetoxy-21-azidopregn-5-en-20-ol (38). The reaction of the $\alpha, \beta$-azidoalcohol 38 with appropriately substituted aromatic aldehydes activated by $\mathrm{BF}_{3} \mathrm{OEt}_{2}$, proceeded cleanly to give the corresponding acetylated product which upon deacetylation in presence of methanolic $\mathrm{NaOCH}_{3}$ yielded the deacetylated D-ring steroidal oxazolines 39 (a-f).

The in vitro cytotoxicity studies of various steroidal isooxazoline and oxazoline derivatives revealed that these derivatives are cell-specific as they were found to be active mostly against the LNCaP (androgen dependent) compared to PC-3 and DU-145 (androgen-independent) prostate cancer cell lines. As compounds 33a, 33e, and 39a were found to be more active than other analogs, it can be assumed that electron-donating groups affect the activity.

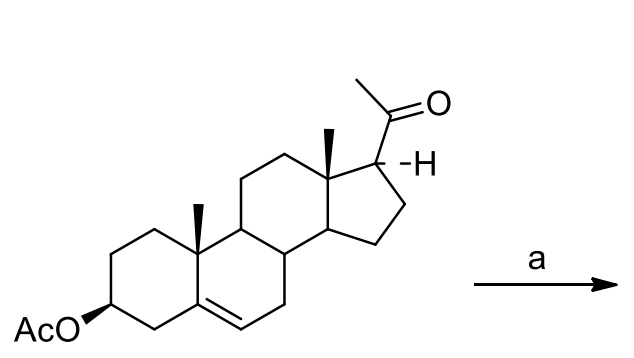

34

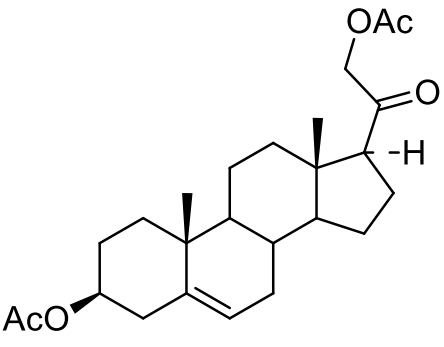

35

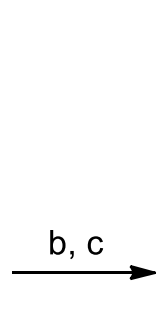

$\mathrm{AcO}$<smiles>C[C@]12CC[C@@H](OC3CC3)CC1=CCC1C2CC[C@]2(C)C1CC[C@H]2C(=O)CO</smiles>

36

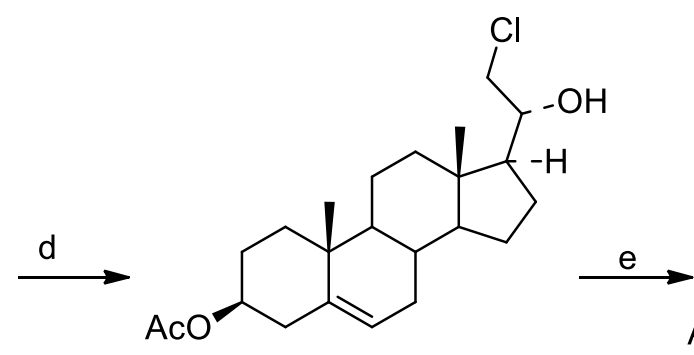

37

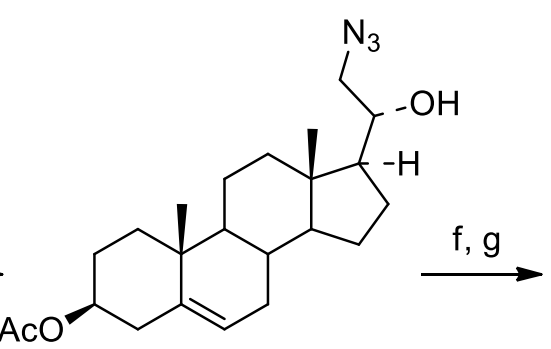

38<smiles>C[C@]12CC[C@@H](O)CC1=CCC1C2CC[C@]2(C)C1CC[C@@H]2[C@H]1CN=C([Al])O1</smiles>

39 (a-f)<smiles>[R]#[W]c1ccccc1</smiles>

a<smiles>CC(C)(C)c1ccc(Cl)cc1</smiles>

b<smiles>Nc1cccc2cc3ccccc3cc12</smiles>

C

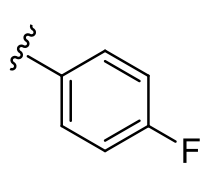

d<smiles>COc1ccc(C)cc1</smiles>

e<smiles>O=[N+]([O-])c1ccccc1I</smiles>

f

Reagents and conditions: $\mathrm{a}-\mathrm{Pb}(\mathrm{OAc})_{4}, \mathrm{BF}_{3} . \mathrm{Et}_{2} \mathrm{O}, \mathrm{MeOH} ; \mathrm{b}-\mathrm{KBH}_{4}, \mathrm{MeOH}$, r.t.; c- $\mathrm{Al}_{2} \mathrm{O}_{3}, \mathrm{MW}$; d- $\mathrm{PPh}_{3}, \mathrm{CCl}_{4}$, reflux; e- $\mathrm{NaN}_{3}$, DMF, $90{ }^{\circ} \mathrm{C}$; f- aromatic aldehydes, $\mathrm{CH}_{2} \mathrm{Cl}_{2}, \mathrm{BF}_{3}$. $\mathrm{Et}_{2} \mathrm{O}$, r.t.; g- $\mathrm{NaOH}$, MeOH, r.t.

Scheme 5. Synthesis of D-ring substituted pregnenolone oxazolines. 
In 2017, bile acid derivatives with an oxazoline ring in the side chain on steroid skeleton were synthesized by Bjedov et al. ${ }^{33}$ and their antitumor activity against human cancer cell lines was investigated.

Protection of carboxylic group in the form of oxazoline can resolve low solubility of bile salt in ether solvents. The synthesis of bile oxazoline derivatives is described in Scheme 6. The sequence included formylation of $\mathbf{4 0}$ and 41, subsequent condensation of the carboxylic group with 2-amino-2-methyl-1-propanol to 44 and 45 using EEDQ as coupling agent followed by cyclization to oxazolines $\mathbf{4 6}$ and $\mathbf{4 7}$ by treatment with thionyl chloride. After deformylation 12-oxo and 3-oxo oxazolines $\mathbf{4 8}$ and $\mathbf{4 9}$ were synthesized in good yields.

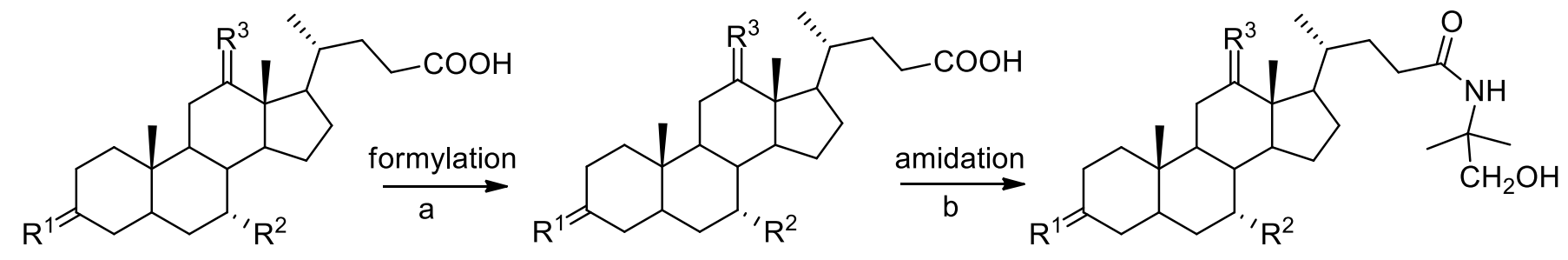
$40 \mathrm{R}^{1}=\alpha \mathrm{OH}, \beta \mathrm{H} ; \mathrm{R}^{2}=\mathrm{OH} ; \mathrm{R}^{3}=\mathrm{O}$
$42 \mathrm{R}^{1}=\alpha \mathrm{OCHO}, \beta \mathrm{H} ; \mathrm{R}^{2}=\mathrm{OCHO} ; \mathrm{R}^{3}=\mathrm{O}$
$44 \mathrm{R}^{1}=\alpha \mathrm{OCHO}, \beta \mathrm{H} ; \mathrm{R}^{2}=\mathrm{OCHO} ; \mathrm{R}^{3}=\mathrm{O}$
$41 \mathrm{R}^{1}=\mathrm{O} ; \mathrm{R}^{2}=\mathrm{OH} ; \mathrm{R}^{3}=\alpha \mathrm{OH}, \beta \mathrm{H}$
$43 \mathrm{R}^{1}=\mathrm{O} ; \mathrm{R}^{2}=\mathrm{OCHO} ; \mathrm{R}^{3}=\alpha \mathrm{OCHO}, \beta \mathrm{H}$
$45 \mathrm{R}^{1}=\mathrm{O} ; \mathrm{R}^{2}=\mathrm{OCHO} ; \mathrm{R}^{3}=\alpha \mathrm{OCHO}, \beta \mathrm{H}$
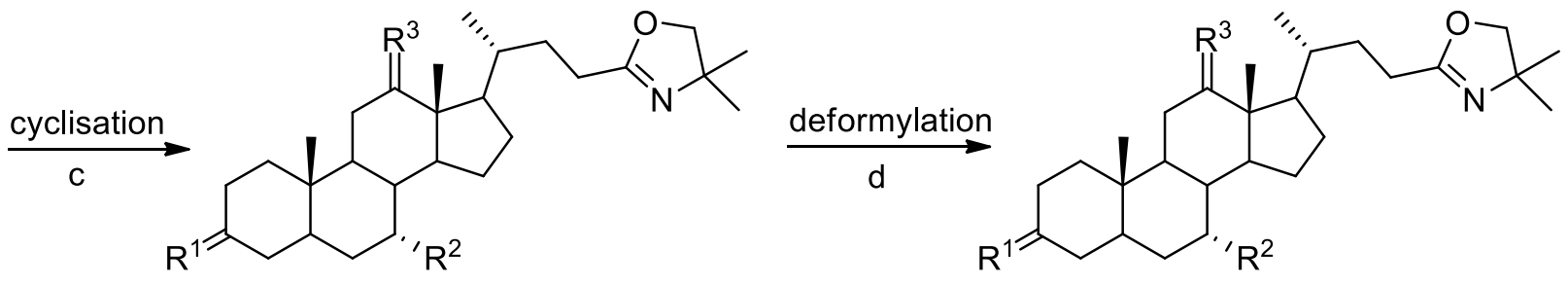

$46 \mathrm{R}^{1}=\alpha \mathrm{OCHO}, \beta \mathrm{H} ; \mathrm{R}^{2}=\mathrm{OCHO} ; \mathrm{R}^{3}=\mathrm{O}$
$47 \mathrm{R}^{1}=\mathrm{O} ; \mathrm{R}^{2}=\mathrm{OCHO} ; \mathrm{R}^{3}=\alpha \mathrm{OCHO}, \beta \mathrm{H}$

$48 \mathrm{R}^{1}=\alpha \mathrm{OH}, \beta \mathrm{H} ; \mathrm{R}^{2}=\mathrm{OH} ; \mathrm{R}^{3}=\mathrm{O}$

$49 \mathrm{R}^{1}=\mathrm{O} ; \mathrm{R}^{2}=\mathrm{OH} ; \mathrm{R}^{3}=\alpha \mathrm{OH}, \beta \mathrm{H}$

Reagents and conditions: a- $\mathrm{HCOOH}, \mathrm{HClO}_{4}, 55^{\circ} \mathrm{C}$; b- $\mathrm{NEt}_{3}$, propanol/ $\mathrm{H}_{2} \mathrm{O}, \mathrm{EEDQ}$, reflux, $4 \mathrm{~h}$; c- $\mathrm{SOCl}_{2}$, THF, r.t., $1 \mathrm{~h}$; d- $\mathrm{KOH}, \mathrm{MeOH}$, reflux, 20 min.

Scheme 6. Synthesis of oxazoline derivatives.

Oxazolines 48 and 49 exhibited moderate antitumor activity toward the HeLa cell line but were 2-3-fold more active than cholic acid. The authors noticed interesting structure-activity relations. Thus, altering the carboxylic group to the oxazoline group has a positive effect on cytotoxicity. This observation could influence future work in the design and synthesis of bile acid derivatives.

Timofeev et al. ${ }^{24}$ also described in 2018 the synthesis of oxazolinyl derivatives of [17(20)E]-21-norpregnene 53-55 (Scheme 7). As reported earlier, tosylate $\mathbf{5 0}^{34}$ was transformed to compound $\mathbf{5 1}$ by treatment with methanol in the presence of $\mathrm{CH}_{3} \mathrm{COONa}$ in $85 \%$ yield. Formation of $6 \beta$-methoxy-3 $\alpha, 5 \alpha$-cyclo fragment was accompanied by transesterification of the 21-carboxylic group (additional experiments showed that ethyl esters of pregn-17(20)-en-21-oic acid are transformed to related methyl esters). The methyl ester $\mathbf{5 1}$ was subjected to alkaline hydrolysis and obtained acid $\mathbf{5 2}$ was subjected to reaction with triphenylphosphine, carbon tetrachloride, and ethanolamine, in the presence of triethylamine, to give oxazoline 53 in $62 \%$ yield. Oxazolines 
$\mathbf{5 4}$ and $\mathbf{5 5}$ were prepared from compound $\mathbf{5 3}$ in high yields by acid-catalyzed methanolysis, or treatment with $\mathrm{HCl}$ in tetrahydrofuran, respectively.

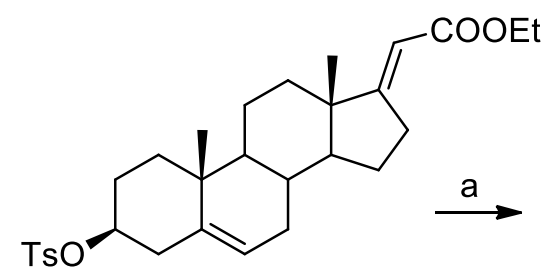

50

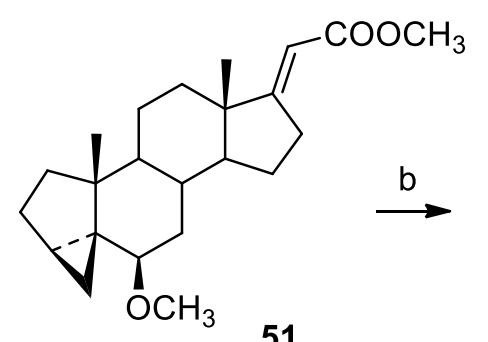

51

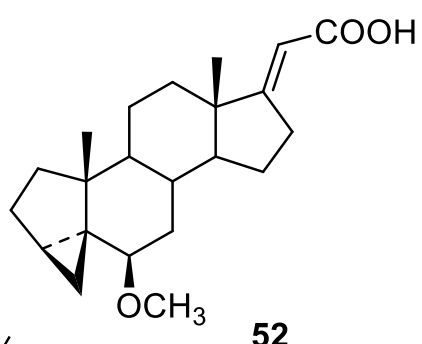

52

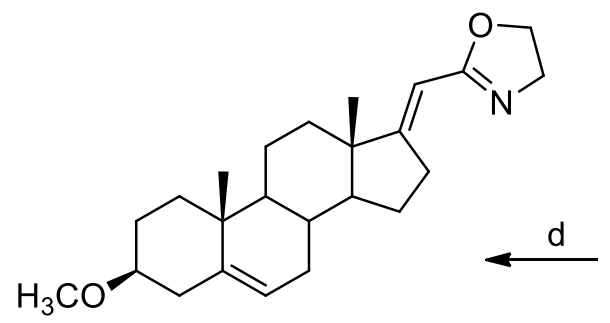

54

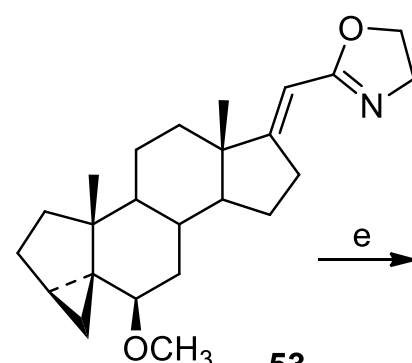

53
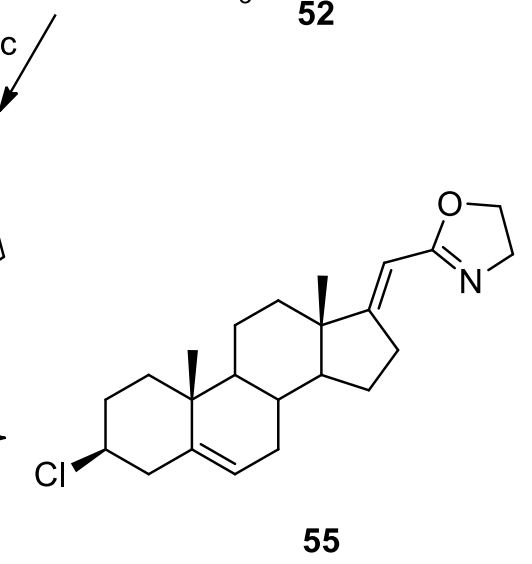

Reagents and conditions: a- $\mathrm{CH}_{3} \mathrm{COONa}, \mathrm{MeOH}$, reflux, $40 \mathrm{~min}$; b- $\mathrm{NaOH} / \mathrm{PrOH}$, reflux, 3h; C- $\mathrm{PPh}_{3}, \mathrm{CCl}_{4} / \mathrm{CH}_{3} \mathrm{CN}, 2^{\circ} \mathrm{C}, 90$ min then $\mathrm{H}_{2} \mathrm{~N}\left(\mathrm{CH}_{2}\right)_{2} \mathrm{OH},\left(\mathrm{CH}_{3} \mathrm{CH}_{2}\right)_{3} \mathrm{~N}, 2{ }^{\circ} \mathrm{C}$, to $20^{\circ} \mathrm{C}, 2 \mathrm{~h}$; d- $\mathrm{MeOH}$, pTSA, reflux, $1 \mathrm{~h}$; e- $1 \mathrm{M} \mathrm{HCl} / \mathrm{THF}$, r.t., $2 \mathrm{~h}$.

Scheme 7. Synthesis of oxazoline derivatives 54 and 55.

For the preparation of oxazoline $\mathbf{6 1}$ comprising seco-A pregnene moiety, ketosteroid $\mathbf{5 6}^{\mathbf{3 4}}$ was chosen as starting compound (Scheme 8). Selective epoxidation of $\Delta^{4}$ with hydrogen peroxide under alkaline conditions led to compound 57 (a mixture of $4 \alpha, 5 \alpha$ - and $4 \beta, 5 \beta$ - epoxides in a ratio of $2: 1$ ) in $83 \%$ yield, which without separation of isomers was subjected to Eshenmoser fragmentation. Treatment of the compound $\mathbf{5 7}$ with $\mathrm{p}$-tosyl hydrazine in dichloromethane - acetic acid mixture led to ethyl ester 59, which was subjected to alkaline hydrolysis, and the resulted acid $\mathbf{6 0}$ was transformed to the oxazoline $\mathbf{6 1}$ in $48 \%$ yield according to the procedure mentioned above.

Oxazolinyl derivative - $\mathbf{6 1}$ moiety efficiently inhibited CYP17A1 activity and prostate carcinoma PC-3 and LNCaP cells growth.

A straightforward methodology has been developed by Montiel-Smith and al. ${ }^{35}$ to access the hitherto unknown spiro steroids bearing oxazolidin-2-one and 2-aminooxazoline motifs at C-17, starting from transandrosterone and estrone. The key intermediates were aminomethyl alcohols $\mathbf{6 6}$ and 67, which upon reaction with triphosgene, or with an alkyl/aryl isothiocyanate, followed by a cyclization, furnished title heterocyclic scaffolds (Scheme 9). 
<smiles>CCOC(=O)C=C1CCC2C3CC=C4CC(=O)CC[C@]4(C)C3CC[C@]12C</smiles>

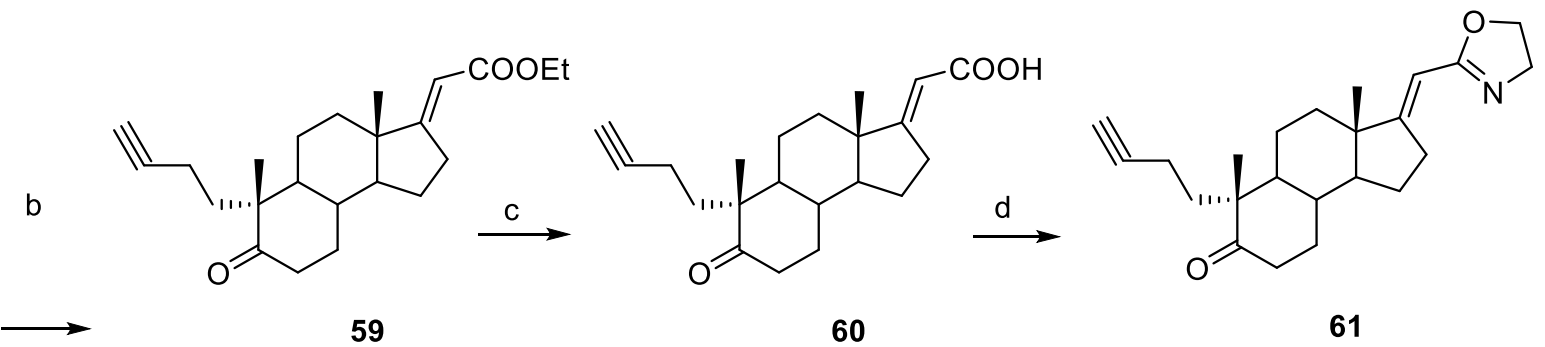

Reagents and conditions: a- $\mathrm{H}_{2} \mathrm{O}_{2}, \mathrm{NaOH} / \mathrm{MeOH}-\mathrm{H}_{2} \mathrm{O}, 2^{\circ} \mathrm{C}, 18 \mathrm{~h}$; b- p- $\mathrm{TsNHNH} \mathrm{NH}_{2} / \mathrm{CH}_{2} \mathrm{Cl}_{2}$ $\mathrm{CH}_{3} \mathrm{COOH}$, r.t., $3 \mathrm{~h}$; c- $\mathrm{NaOH} / \mathrm{PrOH}$, reflux, $3 \mathrm{~h}$; d- $\mathrm{Ph}_{3} \mathrm{P}, \mathrm{CCl}_{4} / \mathrm{CH}_{3} \mathrm{CN}, 2{ }^{\circ} \mathrm{C}, 90 \mathrm{~min}$ then $\mathrm{H}_{2} \mathrm{~N}\left(\mathrm{CH}_{2}\right)_{2} \mathrm{OH},\left(\mathrm{CH}_{3} \mathrm{CH}_{2}\right)_{3} \mathrm{~N}, 2{ }^{\circ} \mathrm{C}$ to $20^{\circ} \mathrm{C}, 2 \mathrm{~h}$.

Scheme 8. Synthesis of oxazoline derivative 61.

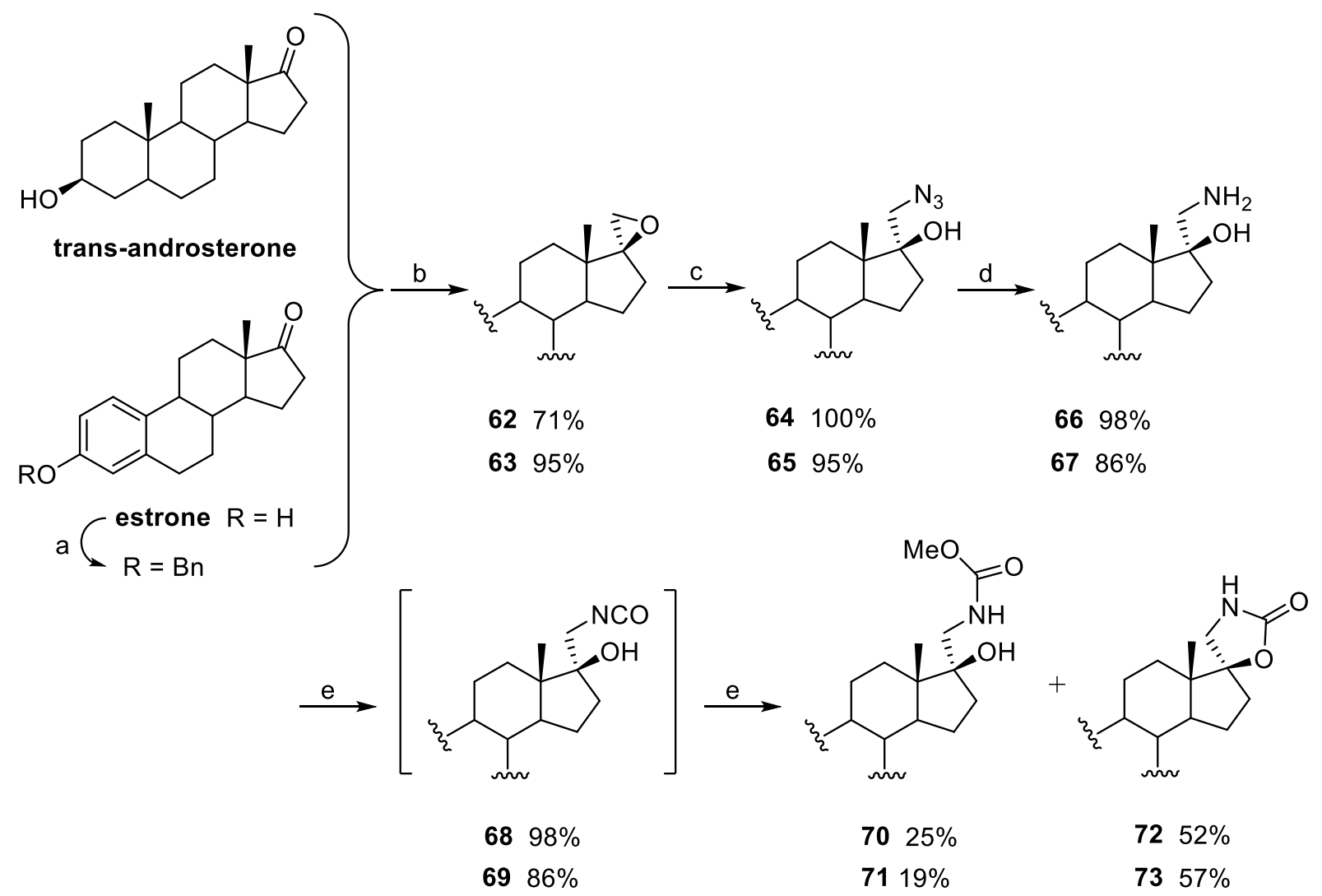

Reagents : a- $\mathrm{BnBr}, \mathrm{K}_{2} \mathrm{CO}_{3}, \mathrm{CH}_{3} \mathrm{CN}$, reflux; b- KOtBu or $\mathrm{NaH}$, DMF; c- $\mathrm{NaN}_{3}, \mathrm{H}_{3} \mathrm{BO}$, DMF, reflux; d- $\mathrm{Pd} / \mathrm{C}, \mathrm{H}_{2}, \mathrm{MeOH}-\mathrm{CH}_{2} \mathrm{Cl}_{2}$; e- triphosgene, $\mathrm{MeOH}-\mathrm{NaHCO}_{3}$ aq.

Scheme 9. Synthesis of oxazolidin-2-ones $\mathbf{7 2 - 7 3}$ from trans-androsterone and estrone. 
In 2020, new oxazoline, benzoxazole, and benzimidazole derivatives were synthesized from $3 \beta$ -

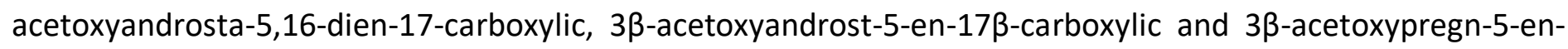
21-oic acids by Pokrovsky et al. ${ }^{36}$

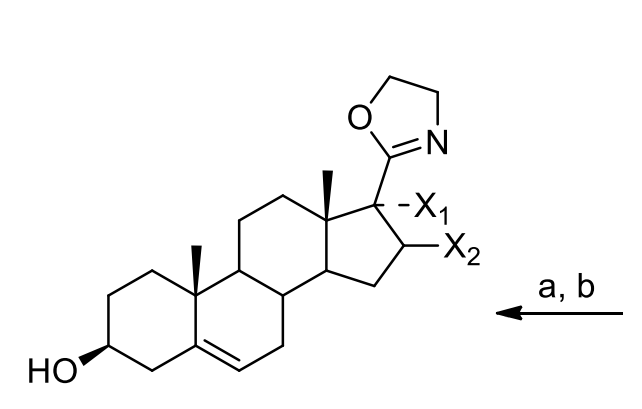

$76 X_{1}, X_{2}=\Delta$

$77 \mathrm{X}_{1}, \mathrm{X}_{2}=\mathrm{H}$

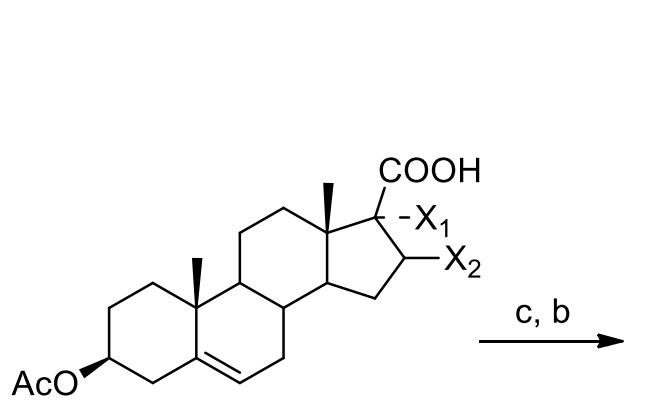

$74 \mathrm{X}_{1}, \mathrm{X}_{2}=\Delta$

$75 \mathrm{X}_{1}, \mathrm{X}_{2}=\mathrm{H}$

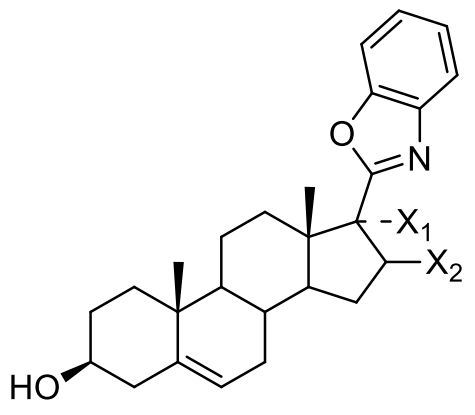

$78 \mathrm{X}_{1}, \mathrm{X}_{2}=\Delta$

$79 \mathrm{X}_{1}, \mathrm{X}_{2}=\mathrm{H}$

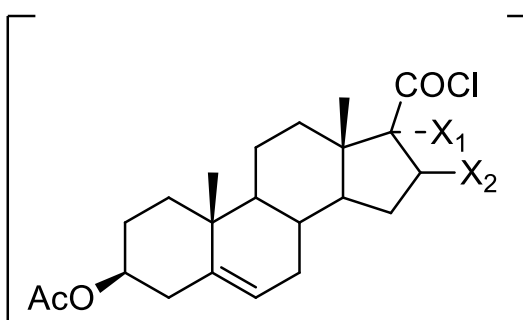

74a $\mathrm{X}_{1}, \mathrm{X}_{2}=\Delta$

75a $X_{1}, X_{2}=H$

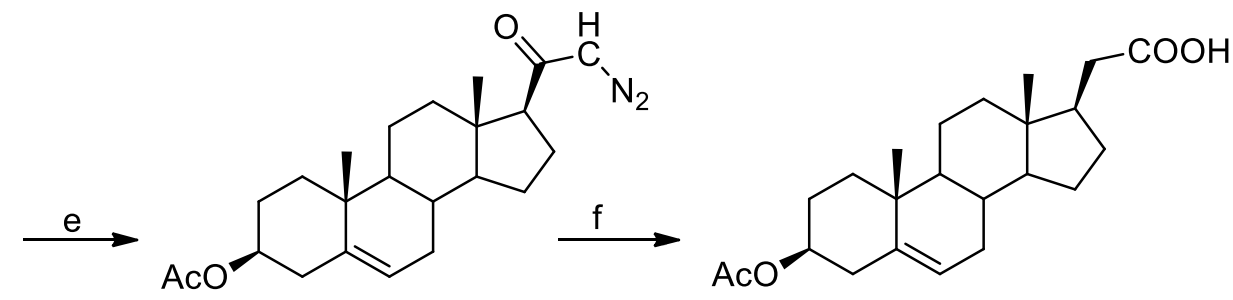

80
81<smiles>CC(C)CC1=NCCO1</smiles>

82

Reagents and conditions: a- $\mathrm{PPh}_{3}, \mathrm{CCl}_{4} / \mathrm{CH}_{3} \mathrm{CN}, 2{ }^{\circ} \mathrm{C}, 2 \mathrm{~h}$ then $\mathrm{NH}_{2}\left(\mathrm{CH}_{2}\right)_{2} \mathrm{OH}, \mathrm{NEt}_{3} / \mathrm{CH}_{3} \mathrm{CN}$, r.t.; b- $\mathrm{K}_{2} \mathrm{CO}_{3} / \mathrm{MeOH}-\mathrm{H}_{2} \mathrm{O}, \mathrm{D}, 40 \mathrm{~min} ; \mathrm{C}-\mathrm{PPh}_{3}, \mathrm{CCl}_{4} / \mathrm{CH}_{3} \mathrm{CN}, 2^{\circ} \mathrm{C}, 2 \mathrm{~h}$ then $\mathrm{NH}_{2}\left(\mathrm{C}_{6} \mathrm{H}_{4}\right) \mathrm{OH}, \mathrm{NEt}_{3} / \mathrm{CH}_{3} \mathrm{CN}, 50^{\circ} \mathrm{C}$; d- $(\mathrm{COCl})_{2}$ /toluene, $2^{\circ} \mathrm{C}$ to r.t., 2 h; e- $\mathrm{CH}_{2} \mathrm{~N}_{2}$, r.t., $1 \mathrm{~h}$; f- $\mathrm{H}_{2} \mathrm{O}$, dioxane, $\mathrm{Ag}+, 70^{\circ} \mathrm{C}, 1$ h.

Scheme 10. Synthesis of oxazoline derivative $\mathbf{8 2 .}$

Simple synthesis of target compounds $\mathbf{7 6 - 8 2}$ is presented on Scheme 10. Transformation of acetylated acid $\mathbf{7 5}$ to related homologous acid $\mathbf{8 1}$ was performed by Arndt-Eistert reaction ${ }^{37}$ : compound $\mathbf{7 5}$ was treated with oxalyl chloride, then resulting acyl chloride 75a was treated with an excess of diazomethane to obtain diazo ketone $\mathbf{8 0}$, which rearranged into acid $\mathbf{8 1}$ under heating with aqueous dioxane in the presence of $\mathrm{Ag}^{+}$ions. $3 \beta-$ Acetylated acids $\mathbf{7 4 , 7 5}$, and $\mathbf{8 1}$ were transformed to oxazolines $\mathbf{7 6}, \mathbf{7 7}, \mathbf{8 2}$ according to the procedure described 
by Kostin et al. ${ }^{38}$. Acids $\mathbf{7 4}$ and $\mathbf{7 5}$ were also converted to benzoxazoles $\mathbf{7 8}$ and $\mathbf{7 9}$ according to the procedure described by Timofeev et al. ${ }^{24}$

The synthesized compounds inhibited the growth of prostate carcinoma LNCaP and PC-3 cells at $96 \mathrm{~h}$ incubation; the potency of 2'-(3ß-hydroxyandrosta-5,16-dien-17-yl)-4',5'-dihydro-1',3'-oxazole (76) was superior and could inspire further investigations of this compound as a potential anti-cancer agent.

\section{Synthesis of Steroidal Oxazolidines}

In 1997, 4',4'-dimethylspiro(5 $\alpha$-cholestane-3,2'-oxazolidin)-3'-yloxy 85 (IK-1) and 7 $\alpha, 12 \alpha$-dihydroxy-4',4'dimethylspiro(5 $\beta$-cholan-24-oic-3,2' -oxazolidin)-3'-yloxy acid 89 (IK-2), two stable steroidal nitroxyl radicals, were synthesized by Cighetti et al. ${ }^{39}$ and tested as possible inhibitors of lipid peroxidation, induced by Fenton's reagent in both rat liver microsomes and egg phosphatidylcholine liposomes.

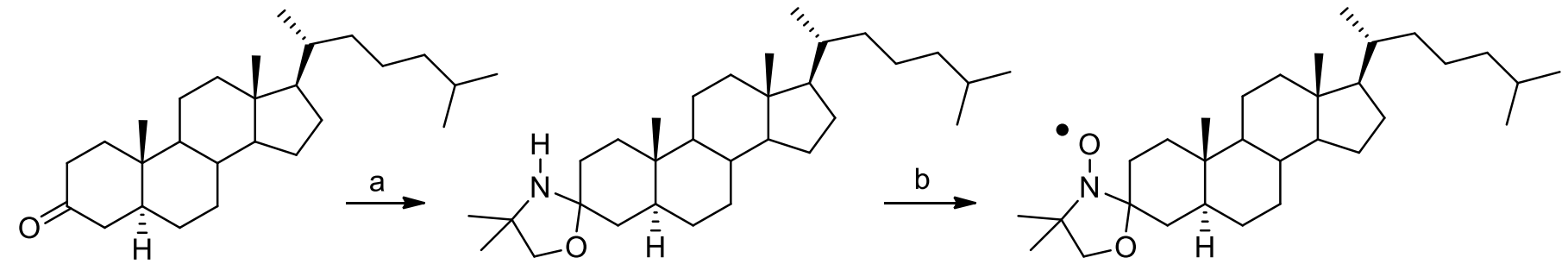

83
84
85: IK-1

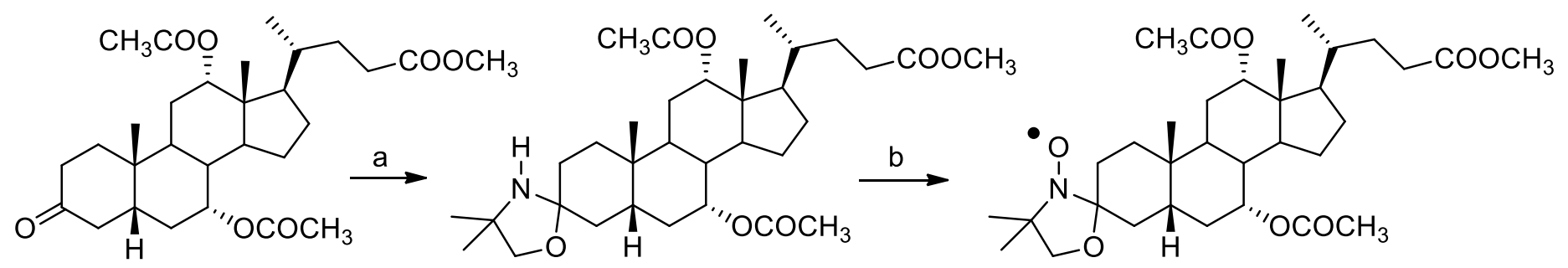

87

88

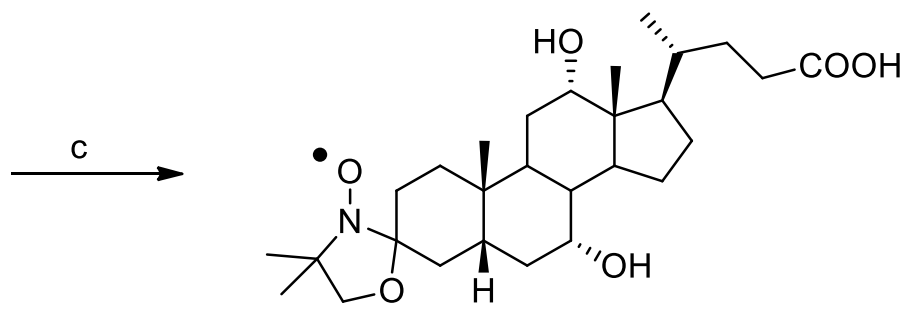

89: IK-2

Reagents and conditions: a- 2-amino-2-methylpropan-1-ol, $p$ TSA, reflux, $48 \mathrm{~h}$; b- $m$-CPBA, $\mathrm{Et}_{2} \mathrm{O}$, r.t., $120 \mathrm{~min}$; $\mathrm{c}-\mathrm{KOH}, \mathrm{CH}_{3} \mathrm{OH}$, reflux, $30 \mathrm{~min}$.

Scheme 11. Synthesis of $4^{\prime}, 4^{\prime}$-dimethylspiro (5 $\alpha$-cholestane-3,2'-oxazolidin)-3'-yloxy 85: IK-1 and $7 \alpha, 12 \alpha-$ dihydroxy-4', 4'-dimethylspiro(5 $\beta$-cholan-24-oic-3,2' -oxazolidin)-3'-yloxy acid 89: IK-2. 
The introduction of the oxazolidinyl moiety into the steroidal nucleus of cholestane or cholic acid was described in Scheme 11 by a two-step general procedure. Treatment of the steroidic ketone 5 $\alpha$-cholestan-3one 83 or $7 \alpha, 12 \alpha$-diacetoxy-3-oxo-5 $\beta$-cholan-24-oate 86 with 2-amino-2-methylpropan-1-ol led to the corresponding oxazolidine 84 or 87 which was treated with $\mathrm{m}$-chloroperbenzoic acid at $0{ }^{\circ} \mathrm{C}$. The nitroxyl derivative 85 (IK-1) was obtained in $68 \%$ yield and 89 (IK-2), after deprotection of 88 with a $\mathrm{KOH}$ methanolic solution, was isolated in $89 \%$ yield.

IK-3 was obtained by chemical reduction of 85 (IK-1) as described in Scheme 12.

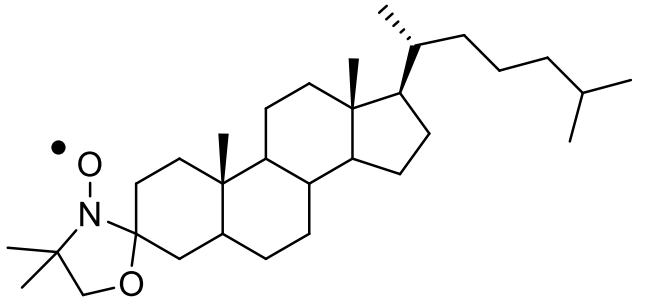

85

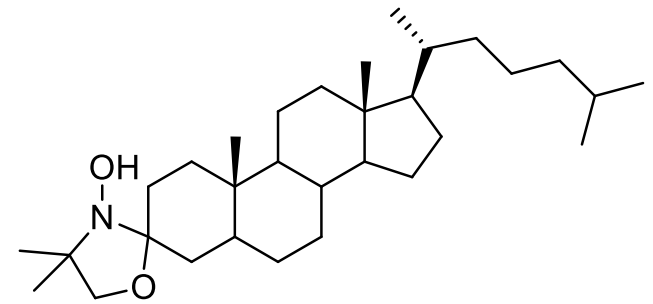

IK-3

Scheme 12. Synthesis of $4^{\prime}, 4^{\prime}$-dimethylspiro (5 2 -cholestane-3,2'-oxazolidin)-3'-hydroxide IK-3.

The inhibitory activity, evaluated through the formation of thiobarbituric acid reactive substances (TBARS) and the conjugated diene, was compared with that of $\alpha$-tocopherol and 2,2,6,6-tetramethylpiperidine-1-yloxy (TEMPO). In each model system IK-1 and IK-2 exhibited an IC50 of $8 \mathrm{mM}$ and reduced the formation of TBARS and conjugated diene, showing IK-1 a potency comparable to $\alpha$-tocopherol and higher than TEMPO. Moreover, $\mathrm{IK}-1$ and, to a lesser extent IK-2, reduced the lipid peroxidation induced in the microsomes by the water-soluble azo-initiator 2,2' -azobis (2-methylpropionamidine) dihydrochloride (AMPH), indicating the IK-1 and IK-2 ability as chain-breaking antioxidants. The hydroxylamine 4',4'-dimethylspiro (5 $\alpha$-cholestane-3,2'-oxazolidin)-3'hydroxide (IK-3) was completely inactive as an inhibitor of lipid peroxidation in heat pre-treated microsomes and liposomes. However, in microsomes, it was active since it was oxidized to the corresponding nitroxyl radical IK-1. The more lipophilic, IK-1, confirms that a good affinity for cell membranes improves the activity of lipid peroxidation inhibitors.

In 1999, Schafiullah et al. ${ }^{40}$ reported a convenient preparation of some steroidal 1',3'-oxazolidin-2' -ones 9395) in good yields (Scheme 13).
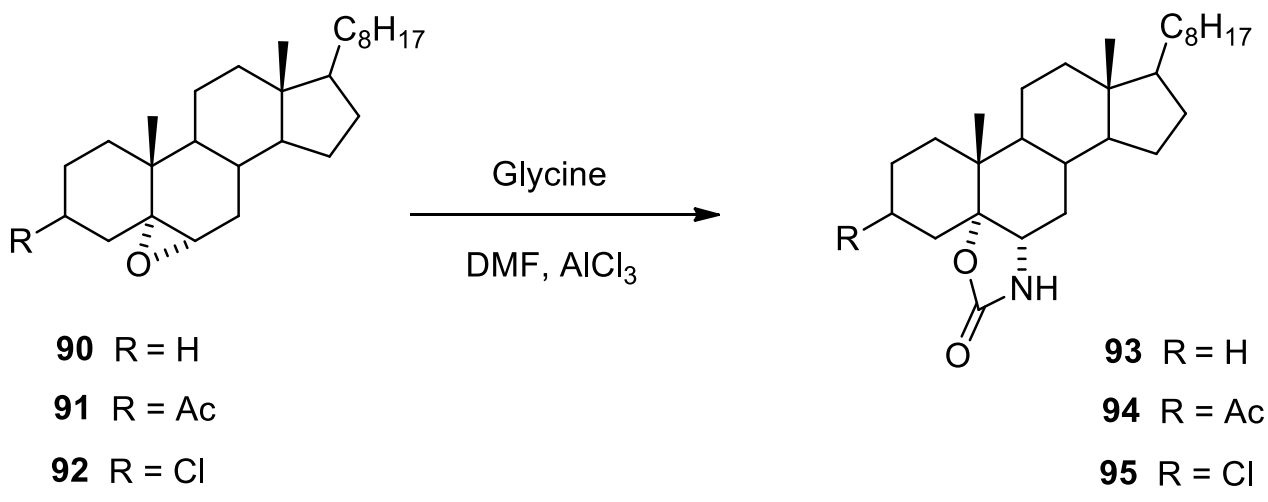

Scheme 13. Synthesis of steroidal oxazolidines 93-95. 
Reaction of $5 \alpha, 6 \alpha$-epoxycholestane (90), its $3 \beta$-acetoxy and $3 \beta$-chloro analogues 91 and $\mathbf{9 2}$, respectively, with glycine in dimethylformamide using $\mathrm{AlCl}_{3}$ as catalyst gave $5 \alpha$-cholestano[6 $\alpha, 5 \alpha$-d]oxazolidine-2' -one 93, its $3 \beta$-acetoxy and $3 \beta$-chloro analogues 94 and 95 , respectively.

In 2008, Schneider et al. ${ }^{41}$ reported the syntheses of a variety of steroidal compounds with the common structural feature of a C-17, as presumed inhibitors of $P 450_{17 \alpha}$.

For the synthesis of the 2-oxazolidone ring at position $17 \beta$ of the sterane skeleton, they chose cyclization of the $\alpha, \beta$-haloalkyl- $N$-arylurethanes in alkaline media. To prepare the $\alpha, \beta$-diol system on the steroidal side-chain, they chose $3 \beta$-acetoxypregn-5-en-20-one (34) as starting compound (Scheme 14). Oxidation with $\mathrm{Pb}(\mathrm{OAc})_{4}$ in the presence of $\mathrm{BF}_{3} \cdot \mathrm{OEt}_{2}$ furnished 3 3 ,21-diacetoxypregn-5-en-20-one (35). Reduction with $\mathrm{KBH}_{4}$ gave two

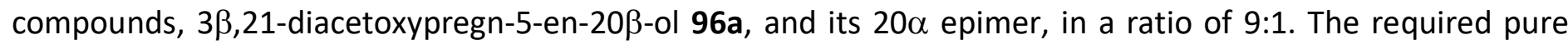
epimer 96a was obtained by flash chromatography. Its selective deacetylation on alkaline alumina was carried out by an earlier developed method to obtain $\mathbf{9 6 b} .{ }^{42}$ For the formation of substituted phenylurethane derivatives 97a-f, the starting compound was 3 $\beta$-acetoxy-21-chloromethylpregn-5-en-20 $\beta$-ol (96c), which was prepared by the Appel reaction of $\mathbf{9 6 b} .^{32}$ Chloro compound $\mathbf{9 6 c}$ reacted with phenyl isocyanate or substituted phenyl isocyanates in the presence of triethylamine to afford the desired 21-chloromethylpregn-5-en-20 $\beta$ arylurethanes 97a-f. Compounds 97a-f were subjected to methanolysis in the presence of four equivalents of $\mathrm{NaOCH}_{3}$. Under these experimental conditions, $\mathrm{N}$-phenyl-2-oxazolidone 98a, (4'-substituted- $N$-phenyl)-2oxazolidones $\mathbf{9 8 b}$-e and ( $3^{\prime}, 5^{\prime}$-disubstituted- $N$-phenyl)-2-oxazolidone $\mathbf{9 8 f}$ were formed in rapid reactions. The cyclization can be explained by the nucleophilic attack of the nitrogen atom of the deprotonated acid amide. This cyclization process is typical neighboring group participation. In the notation proposed by Winstein and Boschan, ${ }^{43}$ the process can be characterized by the symbol $\left(\mathrm{N}^{-}-\mathbf{9 8}\right)$ (Scheme 14). For the formation of the unsubstituted $3 \beta$-acetoxy-17 $\beta$-(2'-oxazolidon-5'-yl)androst-5-ene 101, they used a one-pot cyclization process developed earlier for the formation of cyclic carbamates of amino sugars. ${ }^{44}$ Starting from $3 \beta$-acetoxy-21chloropregn-5-en-20 $\beta$-ol $(96 \mathrm{c})^{42}$ and $\mathrm{Ph}_{3} \mathrm{P}$, the 3 $\beta$-acetoxy-21-phosphiniminopregn-5-en-20 $\beta$-ol was formed, which reacted with $\mathrm{CO}_{2}$ in situ to give an isocyanate intermediate. This isocyanate reacts with the participation of the sterically favored $20 \beta-\mathrm{OH}$ group, yielding the required steroidal cyclic carbamate 101.

The inhibitory effects (IC50) of these compounds on rat testicular C17,20-lyase were investigated with an in vitro radioligand incubation technique. The $N$-unsubstituted $17 \beta$-(2-oxazolidon-5-yl)-androst-4-en-3-one derivative 103 was found to be a potent inhibitor (IC50 = 3.0 $\mu \mathrm{M})$.

In 2012, a new diversity-oriented synthesis (DOS) methodology was developed by Poirier et al. ${ }^{45}$ to generate different types of oxazinones, oxazolidinones from $\beta$-amino diols, which can be easily obtained from ketones (Scheme 15). Considering a large number of natural products and synthetic templates bearing a ketone functionality, this DOS methodology opens the door to the exploration of chemical space regions around the ketone and will favor the discovery of bioactive compounds.

The estrone, first protected as a methoxymethyl ether at the 3-position, was submitted to an aldol condensation reaction with benzaldehyde by using $\mathrm{KOH}$ in refluxing ethanol (1st level of diversity) to give corresponding enone 104 in high yield. Epoxidation of enone 104 was, however, more problematic and needed investigation. Therefore, the authors decided to stereoselectively reduce the enone to generate the corresponding allylic alcohol 105 and then use it as directing the group to favor epoxidation. Enone 104 was thus reduced by using sodium borohydride in methanol and exclusively gave $17 \beta-\mathrm{OH} 105$. This simple modification in the synthetic sequence of reaction order, by performing first the reduction of the 17-ketone and then the epoxidation, resolved the epoxidation problem. High yield of epoxides 106a and 106b were obtained by using $m$-CPBA in DCM with a ratio of $\alpha$-/ $\beta$-epoxides (35:65). This ratio is explained by the directing effect of the $17 \beta-\mathrm{OH}$ group, which favors the attack of the peracid from the $\beta$-face of the olefin. Aminolysis was done 
using a microwave heating approach described for the opening of hindered epoxides. ${ }^{46}$ It was found that 3 equiv of the amine in ethanol at $180{ }^{\circ} \mathrm{C}$ gave a complete reaction. The opening of $\beta$-epoxide $106 \mathrm{~b}$ was easier (90 min) than the opening of $\alpha$-epoxide $106 a(8 \mathrm{~h})$.<smiles>CC(=O)O[C@H]1CC[C@@]2(C)C(=CCC3C4CC[C@H](C(C)=O)[C@@]4(C)CC[C@H]32)C1</smiles>

34

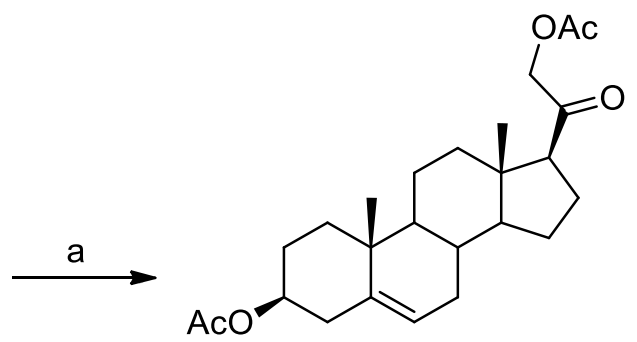

35

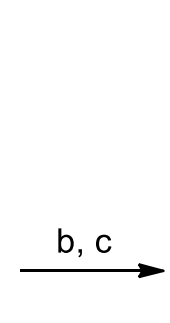

$\mathrm{R}$<smiles>[R]N1C[C@H](CCC)OC1=O</smiles><smiles>[R]CC(O)[C@H]1CCC2C3CC=C4C[C@@H](OC(C)=O)CC[C@]4(C)C3CC[C@]21C</smiles>

96<smiles>[R]N1C[C@H]([C@H]2CC[C@H]3[C@@H]4CCC5=CC(=O)CC[C@]5(C)[C@H]4CC[C@@]23C)OC1=O</smiles>

100

97

$\mathrm{h}$

$98 \mathrm{R}^{1}=\mathrm{H}$

$99 R^{1}=A c$

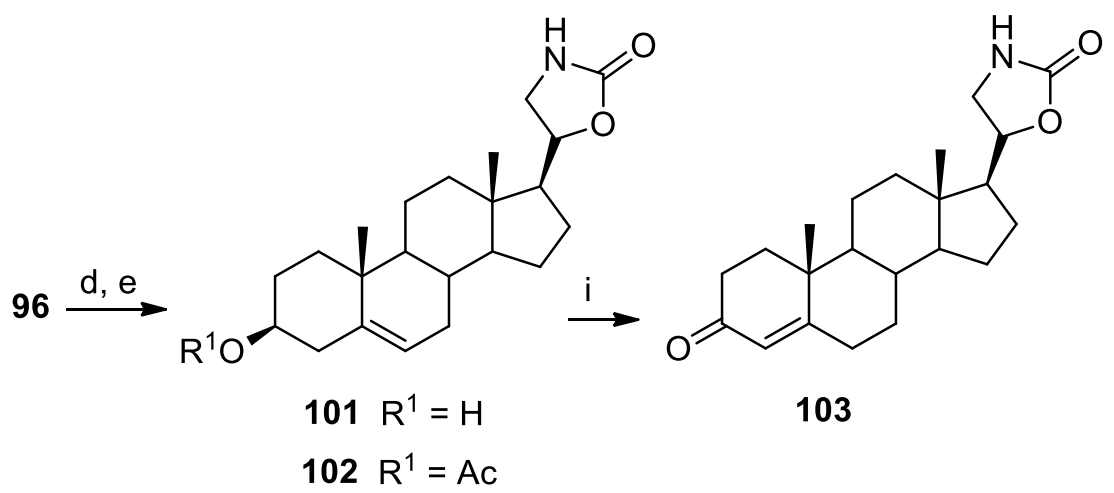

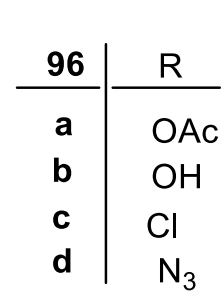

$102 \mathrm{R}^{1}=\mathrm{Ac}$

\begin{tabular}{c|l} 
97, 98, & \\
$\mathbf{9 9 , 1 0 0}$ & $\mathrm{R}$ \\
\hline a & phenyl \\
b & 4-fluorophenyl \\
$\mathbf{c}$ & 4-chlorophenyl \\
d & 4-bromophenyl \\
e & 4-methoxyphenyl \\
f & 3,5-dimethylphenyl
\end{tabular}

Reagents and conditions: a- $\mathrm{Pb}(\mathrm{OAc})_{4}, \mathrm{BF}_{3}$. $\mathrm{Et}{ }_{2} \mathrm{O}, \mathrm{MeOH}$; b- $\mathrm{KBH}_{4}, \mathrm{MeOH}$, r.t.; c- $\mathrm{PPh}_{3}, \mathrm{CCl}_{4}$, reflux; d- $\mathrm{NaN}_{3}$, DMF, $80^{\circ} \mathrm{C}$; e- $\mathrm{PPh}_{3}, \mathrm{CO}_{2}$, acetone, r.t.; f- $\mathrm{PhNCO}, \mathrm{CH}_{2} \mathrm{Cl}_{2}$, r.t.; g- $\mathrm{NaOMe}, \mathrm{MeOH}$, reflux; h- $\mathrm{Ac}_{2} \mathrm{O}$, pyridine, r.t.; i- $\mathrm{Al}(\mathrm{OiPr})_{3}$, cyclohexanone, toluene, reflux.

Scheme 14. Synthesis of steroidal oxazolidines 100-103.

The challenge was to generate a five-membered ring considering that the formation of a six-membered ring was much faster. Prior oxidation of the $17 \beta-\mathrm{OH}$ group of 107 a to block the formation of the six-membered ring seemed to be the best option. However, selective oxidation of alcohol in the presence of a secondary amine was not obvious. Since the secondary amines are known to easily form imine and $\mathrm{N}$-oxide byproducts with the usual oxidizing reagents ${ }^{47}$, the authors used the polymeric version of 2-iodoxybenzoic acid (PS-IBX) to oxidize the preformed TFA-amine salt in DCM. ${ }^{48}$ The oxidation was completely selective and compound 108 was 
obtained in quantitative yield by simple filtration. In that manner, the sequence of reactions from intermediate 106 could be completely compatible with solution-phase parallel chemistry to rapidly generate libraries of azacycle derivatives. They were also able to selectively obtain five-membered ring 109 from amino diol 107b reacting with triphosgene in the presence of DIPEA. In fact, formation of the six-membered ring was not possible considering the opposite position of the $16 \alpha$-amine and $17 \beta-\mathrm{OH}$ group.<smiles>[R]c1cccc(/C=C2\C[C@H]3[C@H]4CCc5cc(OC)ccc5[C@H]4CC[C@]3(C)[C@H]2O)c1</smiles>

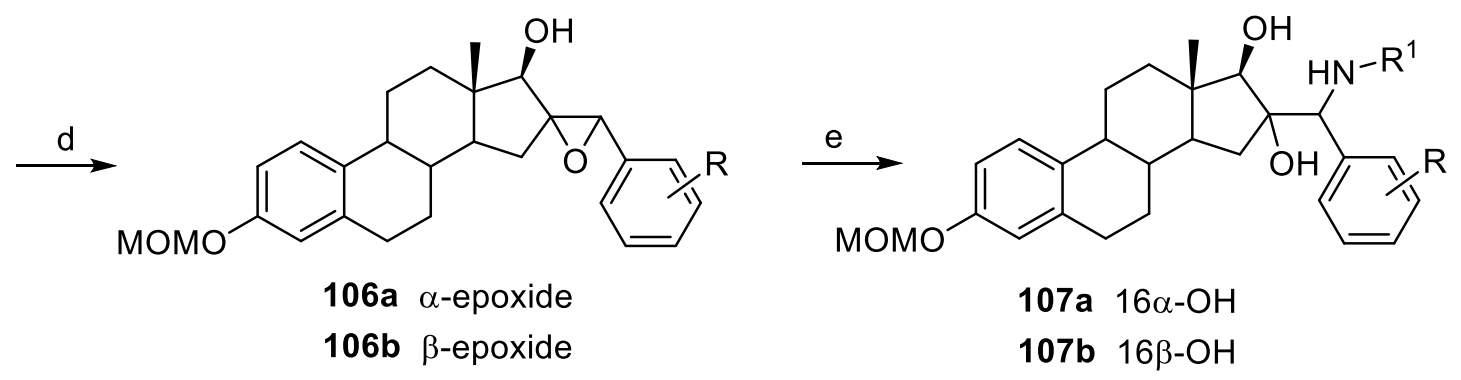

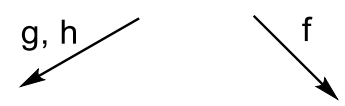<smiles>[R]c1ccc([C@H]2N([R])C(=O)O[C@]23CC2C4CCc5cc(OC)ccc5C4CC[C@]2(C)C3=O)cc1</smiles><smiles>[R]c1ccc([C@H]2C[C@]3(OC(=O)N([R1])[C@@H]3O)[C@@H]3CCc4cc(OC)ccc4[C@H]3CCC2(C)C)cc1</smiles>

Reagents : a- $\mathrm{MOMCl}$, DIPEA, DCM, r.t.; b- benzaldehyde, $\mathrm{KOH}$, EtOH, r.t.; c- $\mathrm{NaBH}_{4}$, $\mathrm{MeOH}$, r.t.; d- m-CPBA, DCM, r.t.; e- $\mathrm{R}^{1}-\mathrm{NH}_{2}$, EtOH, $180^{\circ} \mathrm{C}, \mathrm{MW}$; f- $\mathrm{CO}\left(\mathrm{OCCl}_{3}\right)_{2}$, DIPEA, DCM, r.t.; g- PS-IBX, DCM/TFA (99.5/0.5); h- $\mathrm{CO}\left(\mathrm{OCCl}_{3}\right)_{2}$, DIPEA, DCM, r.t.

Scheme 15. Synthesis of steroidal oxazolidines 108 and 109.

\section{Conclusions}

The present review offers an up-to-date literature on the latest syntheses of steroidal oxazoles, oxazolines and oxazolidinones reported during the last years. Several of these syntheses may be useful, and in particular Poirier et al. ${ }^{45}$ offers an attractive, short and efficient preparation of steroidal oxazinones and oxazolidinones. Overall, 
the interest in steroids and related compounds continue to expand given the diversity of structure and emerging bioactivity inherent in this compound class.

\section{Acknowledgements}

This work has been financially supported by the CNRS and the Ministère de l'Enseignement Supérieur et de la Recherche.

\section{References}

1. Zeelen, J. F. Medicinal chemistry of steroids; Elsevier: Amsterdam, Netherlands, 1990.

2. Trager, L. F. Steroidhormone; Springer: Berlin, 1977.

3. Biellmann, J. F. Chem. Rev. 2003, 103, 2019. http://doi.org/10.1021/cr020071b

4. $\quad$ Nising, C. F.; Bräse, S. Angew. Chem. Int. Ed. 2008, 47, 9389. https://doi.org/10.1002/anie.200803720

5. Hanson, J. R. Nat. Prod. Reports 2010, 27, 887. https://doi.org/10.1039/C001262A

6. Lewis, D. F. V.; Jacobs, M.; Dickins, M. Drug Discov. Today 2004, 9, 530. https://doi.org/10.1016/S1359-6446(04)03115-0

7. Imtiyaz, H. L.; Khaliquz, Z. K.; Bharat, I. F.; Fida, H. Steroids 2013, 78, 945. https://doi.org/10.1016/i.steroids.2013.05.015

8. Zhungietu, G. I.; Dorofeenko, G. N. Russ. Chem. Rev. 1967, 36, 24. https://doi.org/10.1070/RC1967v036n01ABEH001581

9. Li, Y.; Huang, J.; Liu, J.L.; Yan, P. Y.; Liu, H.; Sun, Q. Steroids 2011, 76, 1615. https://doi.org/10.1016/i.steroids.2011.10.003

10. Rafat, M. M.; Wagnat, W. W.; Gamal, A. E.; Rehab, M. S. A. Steroids 2012, 77, 1560. https://doi.org/10.1016/j.steroids.2012.09.004

11. Dwipen, K.; Rupak, K. S.; Ratul, S.; Nabin, C. B.; Jadab, C. S. Steroids 2013, 78, 321. https://doi.org/10.1016/j.steroids.2012.12.003

12. Ranju, B.; Pratap, C. A. Steroids 2012, 77, 552. https://doi.org/10.1016/j.steroids.2012.01.020

13. Duha, C. Y.; Loa, I. W.; Wang, S. K.; Dai, C. F. Steroids 2007, 72, 573. https://doi.org/10.1016/i.steroids.2007.03.010

14. Ibrahim-Ouali, M.; Santelli M. Steroids 2006, 71, 1025. https://doi.org/10.1016/i.steroids.2006.09.006

15. Hanson, J. R. Steroids: partial synthesis in medicinal chemistry. Nat. Prod. Rep. 2006, 23, 100. https://doi.org/10.1039/B512848J

16. Chen, S. J.; Cui, J. G.; Li, Y.; Fan, L. H. Chin. J. Org. Chem. 2011, 187. http://sioc-journal.cn/Jwk_yjhx/EN/Y2011/V31/I02/187

17. Zhang, X. J.; Cui, J. G.; Li, Y.; Chen, S. J. Chin. J. Org. Chem. 2010, 30, 655. http://sioc-journal.cn/Jwk_yjhx/EN/Y2010/V30/105/655 
18. Stulov, S. V.; Misharin A. Y. Chem. Heterocycl. Compd. 2013, 48, 1431.

https://doi.org/10.1007/s10593-013-1158-8

19. Ma, B.; Xiao, Z. Y.; Chen, Y. J.; Lei, M.; Meng, Y. H.; Guo, D. A. Steroids 2013, 78, 508.

https://doi.org/10.1016/j.steroids.2013.02.007

20. Guo, H.; Zhang, G. L.; Zhang, T., He, X. R.; Wu, Z. Y.; Xiao, Y. L.; Pan, Y.; Qiu, G.; Liu, P.; Hu, X. Eur. J. Med. Chem. 2011, 46, 3662.

https://doi.org/10.1016/j.ejmech.2011.05.030

21. Huang, L. H.; Zheng, Y. F.; Lu, Y. Z.; Song, C. J.; Wang, Y. G.; Yu, B.; Liu, H. M. Steroids 2012, 77, 710. https://doi.org/10.1016/i.steroids.2012.03.002

22. Kovács, D.; Mótyán, G.; Wölfling, J.; Kovács, I.; Zupkó, I.; Frank, É. Bioorg. Med. Chem. Lett. 2014, 24, 1265.

https://doi.org/10.1016/j.bmcl.2014.01.069

23. Camoutsis, C. J. Heterocyclic Chem. 1996, 33, 539.

https://doi.org/10.1002/jhet.5570330303

24. 24. Zolottsev, V. A.; Tkachev, Y. V.; Latysheva, A. S.; Kostin, V. A.; Novikov, R. A.; Timofeev, V. P.; Morozevich, Galina E.; Kuzikov, A. V.; Shumyantseva, V. V.; Misharin, A. Y. Steroids 2018, 129, 24. https://doi.org/10.1016/j.steroids.2017.11.009

25. 25. Baranovsky, A. V.; Ladyko, A. S.; Shatskaya, V. A.; Scherbakov, A. M. Russian J. Org. Chem. 2019, 55, 202.

https://doi.org/10.1134/S107042801902012X

26. 26. Baranovsky, A. V.; Bil'dyukevich, V. N.; Golubeva, M. B.; Kuzmitsky, B. B.; Mamchits, Yu. Yu. Russ. J. Bioorg. Chem. 2016, 42, 83.

https://doi-org.lama.univ-amu.fr/10.1134/S1068162015060023

27. Singh, V.; Vedantham, P.; Sahu, P. K. Tetrahedron 2004, 60, 8161.

https://doi.org/10.1016/j.tet.2004.06.096

28. Baranovsky, A. V.; Golubeva, M. B. Chem. Nat. Comp. 2016, 52, 856. https://doi.org/10.1039/C6CC01214K

29. Figueroa-Valverde, L.; Diaz-Cedillo, F.; Rosas-Nexticapa, M.; Mateu-Armand, V.; Pool Gómez, E.; Lopez-Ramos, M; Hau-Heredia, L.; Alfonso-Jimenez, A.; Cabrera-Tuz, J. SN Appl. Sc. 2019, 1, 361. https://doi.org/10.1007/s42452-019-0378-7

30. Banday, A. H.; Giri, A. K.; Parveen, R.; Bashir, N. Steroids, 2014, 87, 93. https://doi.org/10.1016/i.steroids.2014.05.009

31. Wolfling, J; Mernyak, E; Sebok, M; Schneider, G. Collect Czech Chem Commun 2001, 66, 1831. https://doi.org/10.1135/cccc20011831

32. Appel, R; Halstenberg, M; Cadogan, J. Organophosphorous reagents in organic synthesis. New York: Academic Press; 1979, 378-424.

33. Bjedov, S. C.; Jakimov, D.; Posa, M.; Klisuric, O. R.; Saka, M. Tetrahedron 2017, 73, 6932. https://doi.org/10.1016/j.tet.2017.10.058

34. Kostin, V. A.; Zolottsev, V. A.; Kuzikov, A. V.; Masamrekh, R. A.; Shumyantseva V. V.; Veselovsky, A. V.; Stulov, S. V.; Novikov, R. A.; Timofeev, V. P.; Misharin, A. Y. Steroids 2016, 115, 114.

https://doi.org/10.1016/i.steroids.2016.06.002

35. Romero-Hernández, L. L.; Merino-Montiel, P.; Meza-Reyes, S.; Vega-Baez, J. L.; López, Ó.; Padrón, J. M.; Montiel-Smith, S. Eur. J. Med. Chem. 2018, 143, 21.

https://doi.org/10.1016/i.ejmech.2017.10.063 
36. Latysheva, A. S.; Zolottsev, V. A.; Veselovsky, A. V.; Scherbakov, K. A.; Morozevich, G. E.; Pokrovsky, V. S.; Novikov, R. A.; Timofeev, V. P.; Tkachev, Y. V.; Misharin, A. Y. Steroids 2020, 153, 108534.

https://doi.org/10.1016/j.steroids.2019.108534

37. Ye, T.; McKervey, M. A. Chem. Rev. 1994, 94, 1091.

https://doi.org/10.1021/cr00028a010

38. Kostin, V. A.; Zolottsev, V. A.; Kuzikov, A. V.; Masamrekh, R. A.; Shumyantsev, V. V.; Veselovsky, A. V.;

Stulov, S. V; Novikov, R. A.; Timofeev, V. P.; Misharin, A. Y. Steroids 2016, 115, 114.

https://doi.org/10.1016/j.steroids.2016.06.002

39. Cighetti, G.; Allevi, P.; Debiasi, S.; Paroni, R. Chemistry and Physics of Lipids 1997, 88, 97. https://doi.org/10.1016/S0009-3084(97)00052-2

40. Schafiuallah, Sh.; Siddiqui, I. H.; Ansari, S. A.; Khan, E. H. Indian J. Chem 1999, 38B, 600. http://hdl.handle.net/123456789/16449

41. Ondréa, D.; Wölfling, J.; Iványi, Z.; Schneider, G.; Tóthb, I.; Szécsib, M., Julesz, J. Steroids 2008, $73,1375$. https://doi.org/10.1016/i.steroids.2008.06.011

42. Wölfling, J.; Mernyák, E.; Sebök, M; Schneider, G. Collect. Czech. Chem. Commun. 2001, 66, 1831. https://doi.org/10.1135/cccc20011831

43. Winstein, S.; Boschan R. J. Am. Chem. Soc. 1950, 72, 4669.

https://doi.org/10.1021/ja01166a090

44. Kovács, J.; Pintér, I.; Messmer A. Carbohydr Res 1985, 141, 57.

https://doi.org/10.1016/S0008-6215(00)90755-9

45. Maltais, R.; Poirier, D. Eur. J. Org. Chem. 2012, 28, 5435. https://doi.org/10.1002/ejoc.201200852

46. Desai, H.; D’Souza, B. R.; Foether, D.; Johnson, B. F.; Lindsay, H. A. Synthesis 2007, 902. https://doi.org/10.1055/s-2007-965927

47. Müller, P.; Gilabert. D. M. Tetrahedron 1988, 44, 7171. https://doi.org/10.1016/S0040-4020(01)86085-3

48. Sorg, G.; Mengel, A.; Jung, G.; Rademann, J. Angew. Chem. Int. Ed. 2001, 40, 4395. https://doi.org/110.1002/1521-3773(20011203)40:23<4395::aid-anie4395>3.0.co;2-r

\section{Authors' Biographies}

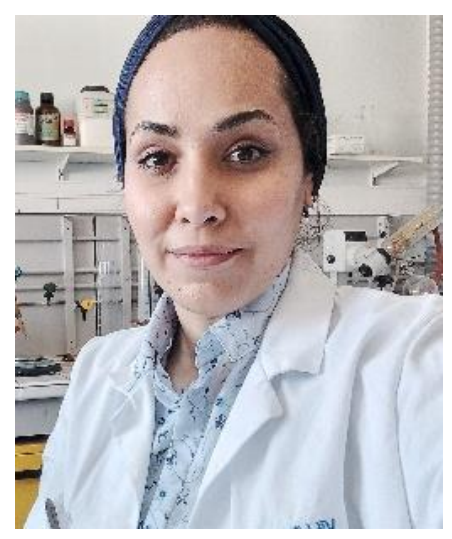

Besma Bendif was born in 1987 in El Biar, Algeria. She has graduated from Alger University, Faculty of Science, Algeria in 2010 then she got her M.Sc degree in 2015. 


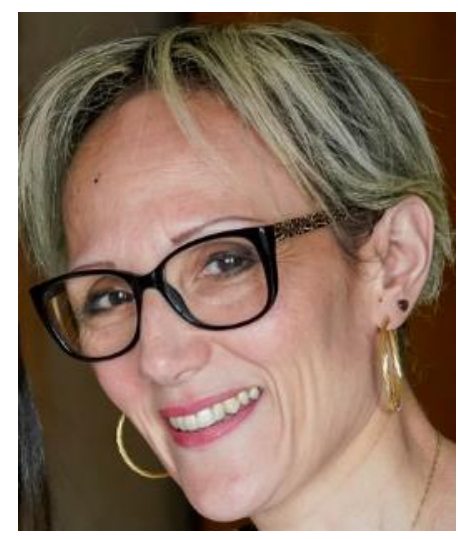

Malika Ibrahim-Ouali carried out her Ph.D. under the supervision of Professor Gramain in Clermont-Ferrand (France) in 1996. The work was focused on the synthesis of alkaloids. She was a postdoctoral fellow with Prof. Knochel (Humboldt fellowship) in 1996 in Germany where she got her first training in organometallic chemistry. In 1997, she joined Professor H. P Husson's group at the ICSN (Paris) as a postdoctoral researcher. Since 1998, she is currently an assistant professor at Aix-Marseille University and her field of interest remains the total synthesis of natural compounds.

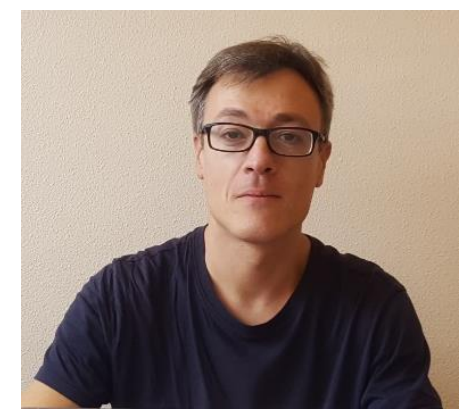

Frédéric Dumur received his Ph.D. in chemistry in 2002 from the University of Angers (France) under the supervision of Professor Pietrick Hudhomme. After Post-Doctoral studies at the University of Groningen (The Netherlands), Reims Champagne-Ardennes (France) and Versailles Saint-Quentin-en-Yvelines (France), he joined the Faculty of Sciences at Aix-Marseille University in 2008, where he is currently working as an Associate Professor. His research interests include the synthesis of phosphorescent dopants for OLEDs and photoinitiators of polymerization. He co-authored about 300 publications and 5 book chapters. 